University of Louisville ThinkIR: The University of Louisville's Institutional Repository

Electronic Theses and Dissertations

$12-2015$

\title{
Impact of urban factors and invasive species on white-footed mouse (Peromyscus leucopus) habitat use and foraging behavior in an urban forest park.
}

William Persons

University of Louisville

Follow this and additional works at: https://ir.library.louisville.edu/etd

Part of the Behavior and Ethology Commons, Other Animal Sciences Commons, and the Population Biology Commons

\section{Recommended Citation}

Persons, William, "Impact of urban factors and invasive species on white-footed mouse (Peromyscus leucopus) habitat use and foraging behavior in an urban forest park." (2015). Electronic Theses and Dissertations. Paper 2313.

https://doi.org/10.18297/etd/2313

This Doctoral Dissertation is brought to you for free and open access by ThinkIR: The University of Louisville's Institutional Repository. It has been accepted for inclusion in Electronic Theses and Dissertations by an authorized administrator of ThinkIR: The University of Louisville's Institutional Repository. This title appears here courtesy of the author, who has retained all other copyrights. For more information, please contact thinkir@louisville.edu. 
IMPACT OF URBAN FACTORS AND INVASIVE SPECIES ON WHITE-FOOTED MOUSE (PEROMYSCUS LEUCOPUS) HABITAT USE AND FORAGING BEHAVIOR IN AN URBAN FOREST PARK

\author{
By \\ William Persons \\ B.A. University of Louisville, 2010

\begin{abstract}
A Dissertation
Submitted to the Faculty of the

College of Arts and Sciences of the University of Louisville

In Partial Fulfillment of the Requirements

for the Degree of
\end{abstract}

Doctor of Philosophy in Biology

Department of Biology

University of Louisville

Louisville, Kentucky

December 2015 

IMPACT OF URBAN FACTORS AND INVASIVE SPECIES ON WHITE-FOOTED MOUSE (PEROMYSCUS LEUCOPUS) HABITAT USE AND FORAGING BEHAVIOR IN AN URBAN FOREST PARK

\author{
By \\ William Persons \\ B.A. University of Louisville, 2010
}

A Dissertation Approved on

June 26, 2015

By the following Dissertation Committee:

Dr. Perri Eason

Dr. Margaret Carreiro

Dr. James Alexander

Dr. Steve Yanoviak

Dr. Tim Carter 


\section{DEDICATION}

This Dissertation is dedicated to my wife

\section{Lyric Persons}

who helped in numerous ways to make this a reality. 


\section{ACKNOWLEDGEMENTS}

I would like to thank the numerous undergraduate students who helped me in the field, including Jenna Wissing, Lindsay Nason, Shelby Sizemore, and Paige Wilson. I would also like to thank Gavin Bradley and Jesse Helton, two fellow graduate students who helped with field work and provided advice.

I would like to thank Dr. Perri Eason and the rest of my committee members for their help ensuring my research project was as complete as possible, especially through the formulation and completion of the final two chapters. While my particular committee shifted composition multiple times, Dr. Margaret Carreiro stuck with me throughout and I am very grateful. It was through the ecology classes I took with Dr. Carreiro as an undergraduate and graduate student that I formed much of my background ecological knowledge.

Dr. Perri Eason accepted the role of my principal advisor after the departure of my original advisor, and helped steer this work back on track. Truly without her guidance and assistance, I would not have completed my Doctorate, for which I will be always 
grateful. Dr. Eason served as my sounding board and guide post throughout my project, keeping me on track and reminding me of what was important. Both Margaret and Perri believed in me from my undergraduate days through the completion of this work, and their support always gave me strength.

I will always appreciate the time and advice given by Dr. Steve Yanoviak. I would appear at his door with an innocent question, and leave 45 minutes later with answers I didn't know I needed but that always helped immensely. Steve provided the strong personality and steady hand that guided me across rough waters on multiple occasions.

Dr. Tim Carter joined my committee from Ball State, and welcomed me into his home for a night when I first met with him. I am grateful for the advice and guidance he provided me on that trip, which helped give me direction and purpose at a critical time in my progression. He allowed me to present my research to his lab, and made me feel that I and my work were important at a time when I doubted myself.

Dr. Jim Alexander provided a strong voice and foundation for my research. He helped strengthen my research methodology and kept me grounded. I am grateful for the patience and support of Dr. Alexander through my years at UofL.

I would also like to thank my wife, Lyric Persons, for her tolerance of my trapping and sampling schedules, and her patience in reading through many a rough draft. Doris, Sheryl, Judy, and Terri in the Biology department office helped me with all of my needs, 
and provided a fair bit of mothering and gossip as well. I always tried to help them out when I could, but there is no way I can repay the help they provided me.

This work would not have been possible without the help of Olmsted Park personnel in selecting field sites, and the permissions granted by Olmsted and Metro Parks to work in their parks. Dr. Fell and the Biology Department of UofL funded and supported my research. 


\begin{abstract}
IMPACT OF URBAN FACTORS AND INVASIVE SPECIES ON WHITE-FOOTED MOUSE (PEROMYSCUS LEUCOPUS) HABITAT USE AND FORAGING BEHAVIOR IN AN URBAN FOREST PARK
\end{abstract}

\author{
William Persons
}

June 26, 2015

Urban ecosystems demonstrate high levels of anthropogenic land-use change, modification of abiotic inputs, and altered disturbance regimes; these changes directly alter habitats. These changes result in reduced native biodiversity, creating available niches often filled by invasive species. Urban parks often serve as reserves for native species less suited to survival in urban areas, helping to preserve native biodiversity through mitigation of anthropogenic effects. Understanding what changes affect these urban parks, how the vegetative community responds, and how species (small mammals in particular) modify their behaviors to persist in these areas will increase our ability to manage urban areas for maximum biodiversity.

This research project took place in Twin Parks, a forested bottomland urban park. The vegetative community, habitat structure, human presence, and the small mammal community were assessed at multiple scales. Giving-Up Density was also assessed.

Chapter 1 assesses the habitat at a macro scale, determining what elements of the vegetative community, vertical structure, and environment contribute to patterns of white-footed mouse (Peromyscus leucopus) capture. Chapter 2 assesses habitat selection 
at a microhabitat scale, examining how P. leucopus uses the specific invasive Amur honeysuckle (Lonicera maackii). Chapter 3 examines P. leucopus anti-predator responses in relation to coarse woody debris (CWD) and honeysuckle canopy cover using GivingUp-Density trials.

White-footed mice select for areas of greater canopy cover at the macro scale. White-footed mice selected for areas with more CWD at the micro-scale, while also potentially avoiding higher invasive species richness. White-footed mice preferentially foraged under the honeysuckle canopy in response to changes in temperature and humidity. This study suggests that the interaction between P. leucopus and ground layer invasive species is complex, and that the effect of moonlight may be diminished in this urban park. 


\section{TABLE OF CONTENTS}

ACKNOWLEDGEMENTS . . . . . . . . . . . . . . . . . . . . . iv

ABSTRACT $\ldots \ldots \ldots \ldots \ldots \ldots \ldots \ldots \ldots \ldots \ldots \ldots \ldots \ldots \ldots \ldots$ vii

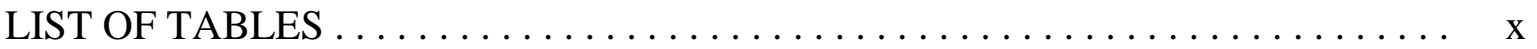

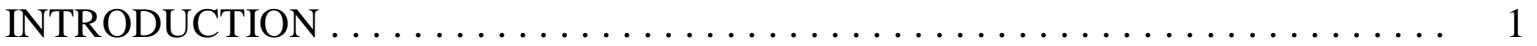

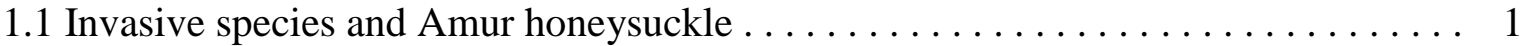

1.2 Small mammals and white-footed mice $\ldots \ldots \ldots \ldots \ldots \ldots \ldots \ldots \ldots \ldots$

CHAPTER 1 - White-Footed Mouse (Peromyscus leucopus) Habitat Use In An

Urban Park Invaded By Amur Honeysuckle (Lonicera maackii) . . . . . . . . . . . . . 5

Introduction ............................... 5

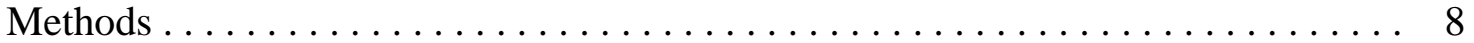

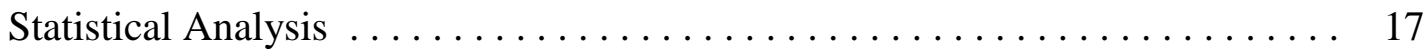

Results .................................... 18

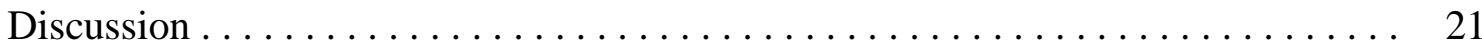

CHAPTER 2 Factors Affecting White-Footed Mouse (Peromyscus Leucopus)

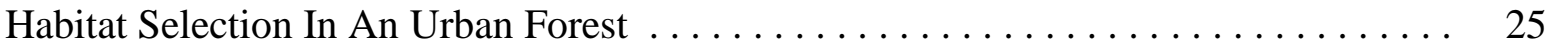

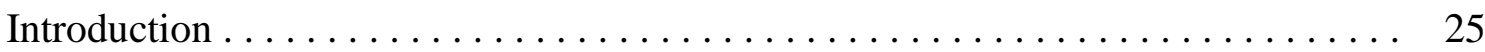

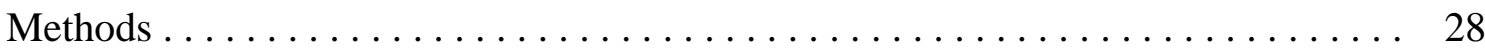

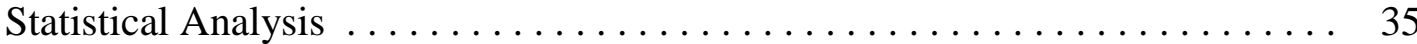

Results ............................... 37

Discussion ................................ 41

CHAPTER 3 Moonlight And Habitat Type Affect Perceived Predation Risk In

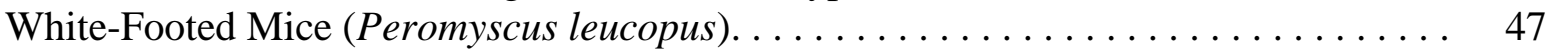

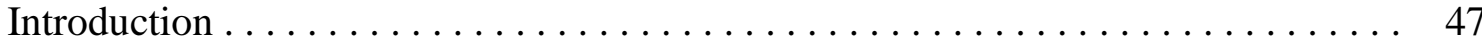

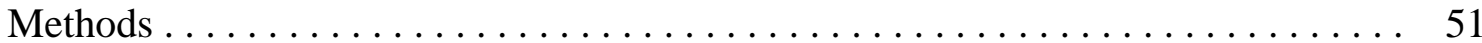

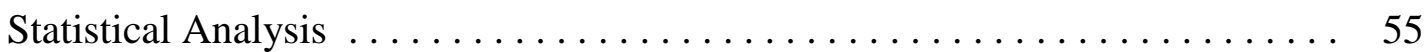

Results ................................. 56

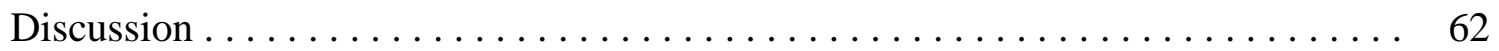

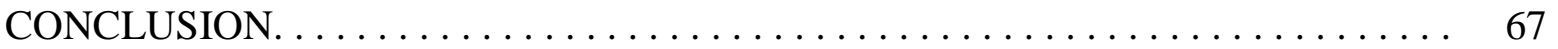

REFERENCES . . . . . . . . . . . . . . . . . . . . . . . . . . . . 70

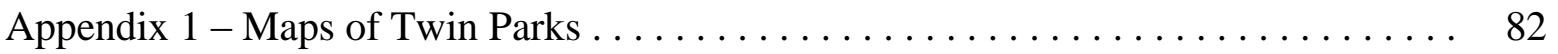

Appendix 2 - Plant Species Identified on Twin Parks $\ldots \ldots \ldots \ldots \ldots \ldots \ldots \ldots$

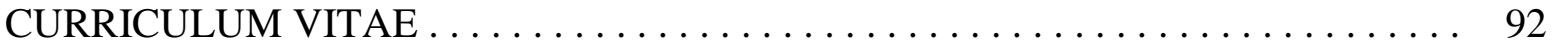




\section{LIST OF TABLES}

TABLE

PAGE

1. Discrete categorical ranking system used to quantify CWD . . . . . . . 13

2. PCA analysis results for the final three factors.............. 20

3. Chi-square analysis of honeysuckle phenology $\ldots \ldots \ldots \ldots \ldots \ldots \ldots$

4. PCA analysis results for the final four factors $\ldots \ldots \ldots \ldots \ldots \ldots \ldots$

5. Stepwise Regression models . . . . . . . . . . . . . . . . 41

6. ANOVA's for vegetative and environmental variables. . . . . . . . . . 59

7. Linear mixed effects models for GUD. . . . . . . . . . . . . . . 60 


\section{INTRODUCTION}

Green areas within urban ecosystems face many influences novel to urban zones (Pickett

et al. 2011). Many abiotic processes such as temperature regime (Oke 1982; Huang et al. 2011), light level (Longcore and Rich 2004), hydrologic cylce (Walsh et al. 2005), nutrient flow (Pickett et al. 2011), and decomposition cycles (Kostel-hughes et al. 1998), are altered in some way. Urban parks can still function as biodiversity hotspots (Nielsen et al. 2014), with a higher degree of complexity helping sustain higher biodiversity (Cornelis and Hermy 2004). The floral and faunal species inhabiting urban parks must also contend with introduced, exotic species (Mckinney 2002).

\subsection{Invasive species and Amur honeysuckle}

Invasion by exotic species is a biotic process that has had a particularly pronounced influence on urban green spaces (McKinney 2006; Lambdon et al. 2008; McKinney 2008). Urban parks and green spaces exist as fragments within a heterogeneous environment (Zipperer and Guntenspergen 2009), and are susceptible to invasion from the large number of introduced exotic species present in urban areas (Chytry et al. 2008; Niggemann et al. 2009). These invasive species work to colonize urban patches, where they often take advantage of increased edge habitat and a loss of specialist species (Fernandez-Juricic 2001; Bartuszevige et al. 2006; McKinney 2006; McKinney 2008). 
Invasive plant species especially can cause significant changes in the communities and habitats they inhabit (Hartman and McCarthy 2008; Lambdon et al. 2008; Vilà et al 2011). They often take advantage of a suppression of ground vegetation through anthropogenic modification (Hobbs 1988; Wilson and King 1995), which creates opportunities for colonization. They also often possess characteristics that allow them to successfully outcompete native species in disturbed urban habitats (Godefroid 2001; Boyce 2010).

Amur honeysuckle (Lonicera maackii Rupr. Maxim.) is a common invasive shrub found in many urban ecosystems in the US (Luken and Thieret 1996; Hutchinson and Vankat 1998), and is able to dominate a habitat and alter ecosystem processes, as well as community composition and structure. Amur honeysuckle creates a dense canopy of vegetation (Hartman and McCarthy 2008) and reduces diversity and abundance of herbs, trees, and shrubs below its canopy through allelopathy and light competition (Deering and Vankat 1999; Collier et al. 2002; Miller and Gorchov 2004; Meiners 2007; Hartman and McCarthy 2008; McEwan et al. 2010). This shrub can dominate the seed bank (Hartman and McCarthy 2008) and is also dispersed by birds (Ingold and Craycraft 1983) and small mammals (Orrock et al. 2010), aiding in its spread.

\subsection{Small mammals and white-footed mice}

Many small mammals living within urban parks are relatively dispersal-limited (Baker $e t$ al. 2003; Angold et al. 2006; Munshi-South 2010), linking their continued survival to their ability to use what habitat and resources are available within a given patch. Many of the species still present tend to be generalist species that are more tolerant of 
fragmentation and anthropogenic disturbances (Francis and Chadwick 2012; Pickett et al. 2011). They also must contend with invasive species, and their ability to manipulate a patch. Over multiple generations, those small mammal species that persist make best use of the invasive species present, potentially resulting in dietary shifts and changes in foraging behavior.

The White-footed mouse, Peromyscus leucopus, is one such small mammal generalist species known to persist within urban parks (Barko et al. 2003; Mahan and O'Connell 2005; Munshi-South 2012). White-footed mice demonstrate broad habitat tolerances, selecting the best microhabitat available (Greenberg 2002; Jones and Lindquist 2012), which facilitates their survival in heavily altered sites (Bellows et al. 2001; Brannon 2005). Amur honeysuckle provides dense canopy cover, which is often selected for by white-footed mice (Edalgo et al. 2009), but the lack of ground vegetation may limit foraging opportunities. Determining what kind of macrohabitat is favored by whitefooted mice in honeysuckle-dominated urban patches will help determine what factors white-footed mice select for.

White-footed mice are known to persist in areas invaded by Amur honeysuckle, sometimes being the only small mammal still present (Mattos and Orrock 2010; Dutra et al. 2011; Rose et al. 2014; Shields et al. 2014). What factors determine P. leucopus microhabitat selection under the canopy depends on what habitat elements still persist. Shields et al. (2014) found leaf litter to be an important determinant of white-footed mouse abundance, but no studies have looked at honeysuckle and P. leucopus in urban 
areas. A standard habitat component that is highly selected for by white-footed mice is coarse woody debris (CWD), which provides both cover and food options (Fauteux et al, 2012; Kellner and Swihart 2014), and would be expected to still be relevant. Whitefooted mice are also known to be semi-arboreal, and may use the honeysuckle canopy for movement or foraging (Batzli 1977). How white-footed mice use honeysuckle microhabitat in a smaller, urban patch will help determine exactly how they view and use L. maackii shrubs.

Previous studies (see Mattos and Orrock 2010; Dutra et al. 2011) have shown that Peromyscus leucopus use Amur honeysuckle canopy as cover from predation. In urban areas the diversity of predators can be reduced, but those present can exist at extremely high densities (Finkler et al. 2011; Hoffmann and Gottschang 1977; Smith and Engeman 2002). Smaller urban parks also may present more opportunities to move beyond the honeysuckle patch, or at least forage along its edge. While forest edge habitat is considered risky habitat (Wolf and Batlzi 2004), if the edge of the honeysuckle patch is within the forest, this may not hold true. White-footed mice would appear to have fewer food options under the honeysuckle canopy as well, due to the suppressed ground vegetation community. White-footed mice did not favor L. maackii berries as a food source in a natural forest (Rose et al. 2014), though they readily eat the berries in lab settings (Williams et al. 1992; Williams 1999Pickett). Understanding how large a role Amur honeysuckle plays in anti-predator behavior within an urban park will provide clues to relative predator pressure, foraging strategies, and the role of the urban environment. 
CHAPTER $1-$

\section{WHITE-FOOTED MOUSE (PEROMYSCUS LEUCOPUS) HABITAT USE IN AN URBAN PARK INVADED BY AMUR HONEYSUCKLE (LONICERA MAACKII)}

\section{INTRODUCTION}

One major concern in urban ecosystems is the loss of native biodiversity as a result of anthropogenic change. Remnant patches of habitat possess the ability to retain species that otherwise would not persist within the heavily altered urban environment (Nielsen et al. 2014), but these areas are threatened by human encroachment, development, and management practices (Pickett et al. 2011). There does exist a mechanism to maintain their potential as biodiversity reserves within urban areas, in the form of urban parks (Nielsen et al. 2014).

Urban parks face many challenges specific to urban ecosystems that affect community composition, biodiversity, and ecosystem function (Pickett et al. 2011). Changes to important abiotic inputs, such as light (Longcore and Rich 2004) and temperature regime (Oke 1982), and ecosystem processes, such as altered hydrology (Walsh et al. 2005) and decomposition cycles (Kostel-Hughes et al. 1998), can potentially affect even the largest 
and most resilient park. Altered disturbance regimes and management plans also affect the functioning of urban parks (Pickett et al. 2011).

In addition to these abiotic factors and altered natural processes affecting a park, there are changes to the biotic community. One of the main factors negatively affecting urban plant communities is the increasing presence of exotic species (McKinney 2006; Lambdon et al. 2008; McKinney 2008). Some exotic species become invasive in urban areas, going beyond simply colonizing a patch or filling a niche to dominating an area. Invasive species modify habitat structure and reduce local biodiversity (Gordon 1998; Pennington et al. 2010), and they can alter food resources for herbivores and seed predators (Manson and Stiles 1998; Williams 1999; Horncastle et al. 2004).

The Amur honeysuckle shrub, Lonicera maackii, is one invasive that has spread across many urban areas (Luken and Thieret 1996; Hutchinson and Vankat 1998), creating a dense canopy formed by adult shrubs (Hartman and McCarthy 2008). This invasive shrub greatly reduces the diversity and abundance of the ground layer through allelopathy and light competition (Deering and Vankat 1999; Collier et al. 2002; Miller and Gorchov 2004; Meiners 2007; Hartman and McCarthy 2008; McEwan et al. 2010 ). Amur honeysuckle can dominate the seed bank (Hartman and McCarthy 2008), producing thousands of berries, each with up to ten seeds (Luken and Thieret 1996). This shrub is also dispersed by birds (Ingold and Craycraft 1983) and small mammals (Orrock et al. 2010), aiding in its spread. 
The small mammal species assemblage in urban parks often contains species with limited dispersal ability, where populations are relatively restricted to the patch they occupy (Munshi-South 2010). This characteristic makes them good indicators of change within the habitat, as their survival is linked to the area they occupy. Those species still extant within urban parks are often tolerant of the fragmentation and have likely adjusted to the resultant changes in vegetative community, as well as anthropogenic disturbances (Francis and Chadwick 2002). How small mammals utilize the habitat as it exists today can provide insight into the relative impact of invasive species as well as other anthropogenic factors. Understanding habitat use of small mammals can also help determine their ability to influence the distribution of plant species.

The white-footed mouse Peromyscus leucopus is a generalist small mammal known to persist within urban parks (Barko et al. 2003; Mahan and O'Connell 2005; Munshi-South 2012). This rodent also persists in areas invaded by Amur honeysuckle, and is sometimes the only small mammal still present in such areas (Mattos and Orrock 2010; Dutra et al. 2011; Rose et al. 2014; Shields et al. 2014). White-footed mice prefer habitats with dense canopy cover (Edalgo et al. 2009), large quantities of woody debris (Drickamer 1990), and relatively little vegetative cover (Barnum et al. 1992), preferences that we would expect to carry over into honeysuckle patches. However, P. leucopus has demonstrated the ability to use whatever habitat is available (Greenberg 2002; Jones and Lindquist 2012), even in heavily disturbed areas (Bellows et al. 2001; Brannon 2005).

In this study, I examine which elements of an urban park best explain the distribution of Peromyscus leucopus. More specifically, I test the effect of Amur honeysuckle on habitat 
selection and distribution of the white-footed mice population. I also evaluate the effects of the vegetative community composition, structural complexity, and canopy cover. I predict that white-footed mice will be located relatively frequently under the honeysuckle canopy, which can provide cover for predator avoidance. I also predict that vegetative diversity and abundance will not play a role in patterns of $P$. leucopus abundance, due to the combined influence of the flood channel and honeysuckle in suppressing the vegetative community.

\section{METHODS}

\section{Study Site}

The study site was Twin Parks, an urban park 4.9 km from downtown Louisville, Kentucky and approximately $500 \mathrm{~m}$ from the Ohio River. This park is 15.59 ha in size, is covered by bottomland Ash-Maple (Fraxinus-Acer) forest, and receives little management. Amur honeysuckle shrubs occupy approximately $75 \%$ of the area of Twin Parks (Appendix 1, Map 1), dominating the mid-canopy layer where they occur. One main gravel path meanders halfway into this park, turning into two divergent dirt paths that experience regular usage by the public. A large windstorm in September 2008 and an ice storm in January 2009 damaged many trees in this park, creating much of the woody debris found on the study plots.

\section{Plot Design}

The plot design consisted of two square plots of four subplots ( $32 \mathrm{~m}$ x $32 \mathrm{~m}$ ) each, set 50 $\mathrm{m}$ apart. The resultant eight subplots each contained nine quadrats $(10.5 \mathrm{~m} \mathrm{x} 10.5 \mathrm{~m})$, for a total of 72 quadrats. Four subplots were within the flood channel and had less than $30 \%$ 
honeysuckle cover. The other four subplots were outside the channel and had greater than $75 \%$ honeysuckle cover. Each quadrat was gridded in $1-\mathrm{m}^{2}$ units (squares) for vegetative sampling, yielding a total of 110 grid squares per quadrat.

\section{Vegetative Sampling}

During the summer 2012, I conducted a pilot vegetative census that sampled all 110 meter squares in all 9 quadrats of plot 1 subplot 1 , and 6 quadrats of plot 1 subplot 4 . A power analysis (Knowware International) based on that initial census showed that sampling 201 -meter square units (squares) would provide an adequate sample size to assess vegetation. Using the random number generator function in Excel, I generated 20 unique numbers from the range 1-110 for each of the 72 quadrats. I used those numbers to select grid squares for vegetation censusing in the 57 quadrats that I had not yet assessed; these censuses were performed in the spring and summer of 2013. For the 15 quadrats already sampled in the pilot vegetative census, only data from the squares that matched the randomly generated numbers were used. This method yielded a total of 1,440 randomly chosen $1-\mathrm{m}^{2}$ grid squares across 72 quadrats.

To census vegetation in the chosen squares I identified the species present and counted the number of individuals for each species. Any grass or sedge that could not be positively identified to species was grouped into a common 'grass' or 'sedge' category. Each species was ranked 1,2, or 3 on a dominance scale. The most dominant plant, based on a combination of size and cover, was ranked 1. Any plant species either tall enough or present in enough numbers to be visible without moving aside any vegetation was ranked 
2. Any plant species whose members were either small enough, or present in low enough numbers, that moving other vegetation was necessary to locate it was ranked 3.

I only included tree seedlings and saplings no more than 1.5 meters tall in the vegetation analysis, as they were not a part of the canopy. I separately identified and measured diameter at breast height (dbh) of all trees found in the 20 randomly selected squares that were over $1.5 \mathrm{~m}$ in height and with a dbh $>3 \mathrm{~cm}$. These larger trees were analyzed separately from the vegetation analysis to understand their relative impact to stand structure and the importance of tree diversity and size. Once all data were collected for all plant species, plants were divided into functional groups: forbs, grasses, sedges, vines, shrubs, and tree seedlings. All exotic species were identified as such.

\section{Honeysuckle Sampling}

All adult and juvenile honeysuckle found in the randomly selected $1 \mathrm{~m}^{2}$ squares were counted and categorized. Due to the differences in stem density, growth form, canopy height, and overall size in adult and juvenile honeysuckle shrubs, they were grouped and analyzed separately. Shrubs were categorized as adults if they formed a part of the midlevel shrub canopy, had the majority of their stems growing outward instead of skywards, and had canopy-directed stems that were well branched. Juvenile shrubs were at least $60 \mathrm{~cm}$ in height and were usually multi-stemmed but had primary stems directed canopywards, with relatively few stems growing outward (Deering and Vankat 1999). Juvenile shrubs can produce berries if in a high light environment, so reproductive condition was not a useful measure of age class. Any honeysuckle shrubs less than $60 \mathrm{~cm}$ in height were 
categorized as seedlings during vegetative sampling and counted as such, but not measured.

Each adult and juvenile honeysuckle shrub present on any of the 20 randomly selected 1 $\mathrm{m}^{2}$ squares was measured. I counted the number of stems for each shrub, and recorded each stem as dead or alive. I measured the dbh of the largest stem of each shrub. For those shrubs that either had significant branching below $1.5 \mathrm{~m}$ or were $<1.5 \mathrm{~m}$ tall, stem diameter was measured below the lowest branching point on the primary stem. The root ball of Lonicera maackii projects out of the soil, providing a relatively flat woody platform from which stems grow. The diameter of the apical root ball was measured across the longest axis, as well as perpendicular to the longest axis. These values were averaged to estimate apical root ball diameter. For analyses, honeysuckle shrubs were categorized according to age and status (alive or dead). Adult and juvenile shrubs were separated to evaluate their relative impact on the surrounding community. Adult honeysuckle shrubs generally grow at lower densities than juveniles, with higher canopies and less ground cover. Honeysuckle variables were then averaged for each quadrat for the following categories for all honeysuckle measured: adult honeysuckle, juvenile honeysuckle, living adult and juvenile honeysuckle, and dead adult and juvenile honeysuckle. An additional variable tallied the number of squares out of 20 on which honeysuckle were present.

\section{Map-based Variables}

I created maps accurate to the square meter for quantification of selected variables across all quadrats. The first map set contained all honeysuckle adults and juveniles, all trees, 
and all coarse woody debris (including snags and fallen $\operatorname{logs}$ ). The second set evaluated shade for all quadrats by square meter. A third map shows flood zone delineations for all quadrats by square meter. The methods and criteria used to create these maps are described below.

\section{Honeysuckle and Coarse Woody Debris Maps}

The first map set allowed all honeysuckle shrubs on each quadrat to be counted. Honeysuckle count variables included all honeysuckle shrubs, then adult honeysuckle and juvenile honeysuckle separately.

Coarse woody debris (CWD) variables were also extracted from these maps, and included fallen logs and snags but not fine woody debris. For the purpose of this study I define coarse woody debris as any sticks from trees or vines that are at least $1 \mathrm{~m}$ long and $3 \mathrm{~cm}$ in diameter. Anything smaller was considered fine woody debris. Leaf litter was not included. CWD was quantified for each square meter on a 0-10 scale (Table 1). A zero value meant 1 or fewer sticks classified as CWD on a square. In many places, large debris tangles or snags created a CWD component that spanned from the ground into the honeysuckle canopy. For defining CWD I consider this an arboreal component of CWD, which indicates CWD connectivity between the ground and the shrub and/or tree canopy from partially fallen vines and/or branches. 
Table 1. Discrete categorical ranking system used to quantify CWD. All scores $>1$ meet the specifications for lower scores

01 or fewer sticks classified as CWD on a square

1 at least 2 branches or vines $\geq 3 \mathrm{~cm}$ in diameter and $>1 \mathrm{~m}$ in length

2 at least one downed tree trunk in addition to 2 branches or vines

33 or more branches that do not cover the entire square; also includes logs

4 the entire square was covered with CWD, leaving no gaps greater than $25 \times 25 \mathrm{~cm}$

5 continuous CWD covering an area $>16 \mathrm{~m}^{2}$

$6 \quad$ CWD debris pile averaged at least $1 / 3 \mathrm{~m}$ in height across the entire square

7 inclusion of a strong arboreal component

8 body of a large snag and corresponding debris

9 ground-level CWD at least $1 \mathrm{~m}$ in height

10 CWD too dense to see through, a strong arboreal component, and the presence of a fallen tree or large branch

Coarse woody debris quantification, outlined in Table 1, followed a logical progression of increasing density and size of debris. Variables quantified from the resultant data examine various aspects of CWD in relation to Peromyscus leucopus. I began by determining the mean CWD for all squares on a quadrat, CWD M. I then excluded squares with no CWD (value $=0$ ) and calculated a mean of all squares with at least some CWD, generating CWD X. I then focused on the CWD levels most selected for by $P$. leucopus; large areas of dense CWD (Greenberg 2002). All squares with a CWD value of 4 or greater would be selected for, creating the variable CWD M4 which represented the mean of all squares with a CWD value of at least 4 . The final mean CWD variable, CWD $5 \mathrm{M}$ targeted the habitat on each quadrat that most directly affected the likelihood of a white-footed mouse entering a trap, the $5 \times 5 \mathrm{~m}$ grid at the center of each quadrat (Greenberg 2002). I also counted the number of squares on each quadrat that contained CWD, and those squares which scored at least a 4. 


\section{Shade Variable Maps}

I estimated \% shade coverage for every square meter on each quadrat. This was done only on sunny days during the summer, between $12: 00 \mathrm{~h}$ and 13:30 $\mathrm{h}$. The $\%$ shade was ranked based on what percentage of a square was shaded; little $(<10 \%)$ shade $=10$; partial $(30 \%-60 \%)$ shade $=20$; and full $(>80 \%)$ shade $=30$. The absence of observed values between $10 \%-30 \%$ and $60-80 \%$ shade resulted from a natural division of shade and canopy.

I also categorized vegetative canopy composition for each square meter. Categories were based on what type of vegetation was providing the cover over a particular square; vines only $=10$, vine and trees $=15$, trees only $=20$, trees and honeysuckle $=25$, and honeysuckle only $=30$. The two components, shade composition and shade amount, were evaluated separately in analyses.

\section{Flood Variable}

Direct flooding was also evaluated for each quadrat from January-December 2012 through 40 visits, spaced 7-10 days apart. On each visit, the amount of standing water and the muddiness of the soil on each quadrat was estimated on a scale of 1-3, with one being standing water, 2 being muddy soils, and three being dry, firm soils. The number of times a quadrat was rated a value of 1 was tabulated to create the variable FloodPeriod. This directly assessed flooding on both plots, and the likelihood of standing water to persist beyond a rain event, as well as saturation time. 


\section{Mammal Trapping}

One Sherman trap $(8.5 \mathrm{~cm}$ x $8.0 \mathrm{~cm}$ x $23.2 \mathrm{~cm})$ was placed on the center of each quadrat, starting spring 2012. This created a 6x6 grid of 36 traps on each plot, with nine traps on each subplot (Figure 1b). Three squirrel-sized $(31 \mathrm{~cm}$ x $26 \mathrm{~cm}$ x $82 \mathrm{~cm})$ Tomahawk traps were placed on each subplot, creating a $3 \times 4$ grid on each plot. One raccoon-sized $(19 \mathrm{~cm}$ $\mathrm{x} 20 \mathrm{~cm} \times 51 \mathrm{~cm}$ ) Tomahawk trap was placed in the center quadrat of each subplot in order to limit disturbance from northern raccoons (Procyon lotor), Virginia opossums (Didelphis virginiana), and eastern grey squirrels (Sciurus carolinensis). Bait consisted of peanut butter and oats for all trap sessions (Yunger 2002; Edalgo and Anderson 2007). Three trapping sessions that were three nights in duration occurred in 2012 (April, June and July), and two trapping sessions that were four nights in duration occurred in 2013 (May and June).

All mammals captured were identified to species, weighed, and sexed, and the capture location of each individual was recorded. All small mammals were also tagged with Monel 1 ear tags (National Band and Tag Co, Newport, Ky). Small mammal species captured in this study included white-footed mouse (Peromyscus leucopus), short-tailed shrew (Blarina brevicauda), and eastern chipmunk (Tamias striatus). Other mammal species captured included eastern grey squirrel, Virginia opossum, northern raccoon, and feral cat (Felis catus). This project was approved under University of Louisville IACUC proposal \#13094, entitled 'Use of Invaded Urban Parks by Small Mammals'. 


\section{Human Presence}

The variable human presence quantified use of this site by visitors to the park other than the author of this study. This variable used ordinal ranking to assess likelihood of human presence on a given quadrat, both as quantity of foot traffic and the duration of use in mini-camps. Indicators of human presence included signs of human paths, the accruing of human trash along clear corridors (cigarette butts and packs, beer cans, etc.), placement, removal or creation of structures for sitting and/or limiting visibility, and direct observation of people. Mini-camps present at this site were areas where park users would return nearly daily to the same spot and occupy it for durations ranging from 10-15 minutes up to several hours. Multiple people usually occupied a camp at the same time, with people coming and going. Use level was determined through direct observation of people.

Human presence was ranked on a scale from 0-10. Any quadrat ranked 0 had no observed human activity and showed no signs of human presence. A rank of 1 meant there were signs of human presence but no observed activity. Ranks 2, 3, and 4 included quadrats where observations of human use occurred at low frequencies. A rank of 2 was assigned if only 1 - 2 observations occurred per year, a 3 if use occurred 3 - 5 times per year, and 4 if there were 6 - 11 occurrences of use yearly. A rank of 5 meant humans used the trail more than 12 times per year, but no visible paths were present. The presence of defined human paths denoted ranks of 6 and higher. Quadrats with regular use leading to the formation of paths combined with no observable camps were scored a 6. Quadrats that experienced heavy or daily use but where camps were never observed scored as 7 . The 
presence of camp that experienced use but was not observed in use along with heavy use of trails ranked an 8. Quadrats ranking a 9 contained one camp experiencing regular, observable use. Quadrats ranking a 10 contained multiple camps that experienced regular to heavy use and were frequently observed occupied.

\section{Statistical Analysis}

Due to the high number of heavily correlated variables, I first used correlation tables to reduce the number of non-independent and confounded variables. When multiple nonindependent explanatory variables were significantly correlated with each other, I selected for retention the independent variable/s (IV) with the lowest p-value score in relation to the dependent variable (DV). If multiple IVs were significant at the same level (i.e. $<0.05,<0.01)$, then I kept the IV with the higher $\mathrm{r}^{2}$ correlation with the DV for further analysis. Those variables remaining were entered into a Principal Component Analysis (IBM SPSS Statistics v. 21.0) in order to identify the variables best able to explain the variation in my dependent variable. I also used PCA to identify the relationships between and among variables through analysis of the component axes. All selected variables were entered into the initial PCA, and variables with a communality under 0.500 were removed from the analysis (Novčić and Damnjanović 2012). A new PCA was run with the reduced variables, and PCAs were run until no more variables fit

conditions for removal. I kept only component axes with eigenvalues $>1$ (Kaiser-Guttman criterion; Jackson 1993). I regressed the PCA component scores against the dependent variable trap success to determine which components had significant effects on trap success. I also generated $\mathrm{r}^{2}$ values in Excel (2010) to compare invasive species diversity with overall plant diversity. 


\section{RESULTS}

The vegetative survey identified 108 unique plant species: 42 forbs, 32 tree species, nine vine species, eight shrubs, six grasses, five sedges, and one fern species. Of the total, eight forb, three tree, three vine, three shrub, and two grass species were exotic. Sixteen tree species were identified as tree seedlings/saplings, and 27 tree species were identified as mature trees. Five species were identified as tree seedlings/saplings only, and 16 species as mature trees only. See Appendix 1 for a list of all plant species sampled. In

general, forb species diversity increased with higher forb abundance $\left(r^{2}=0.49\right)$, and invasive forb diversity increased with total forb diversity $\left(r^{2}=0.31\right)$

For this study, 1,388 trap nights resulted in 127 captures of 78 individual Peromyscus leucopus, including 51 males and 27 females. A final set of 94 captures was used for statistical analysis, with 16 individuals captured twice. Other small mammal captures from Sherman traps included four eastern chipmunks (Tamias striatus) and two shorttailed shrews (Blarina brevicauda). These species were not included in trap success due to small sample size.

\section{PCA and Regression}

The final PCA included 13 variables on three Factors (Table 2) which explained 69.42\% of the variation in trap success. Factor 1 was loaded on most highly by shade type $(0.930)$ and adult honeysuckle abundance (0.769), and it explained $42.45 \%$ of the variation in trap success. Factor 2 explained $16.24 \%$ of this variation and represented vegetative 
variation, with high-loading factors including average abundance of dominant plants (0.791), average abundance of dominant grasses (0.773), and abundance of sedges (0.674). Factor 3 reflected vegetative diversity, with high loadings for exotic species diversity (0.781), exotic vine diversity (0.761), and native shrub diversity (0.683), and explained $10.74 \%$ of the variation in trap success. Regressing the three factor scores against $\%$ trap success produced a model $\left(\mathrm{r}^{2}=0.058, p=0.023, \mathrm{~N}=72\right)$ containing factor $1(\beta=1.704,95 \%$ C.I. $0.238-3.170)$. I then regressed the most significant variable for each of the three axes against the DV \% trap success. This produced a model $\left(r^{2}=0.045\right.$, $p=0.009, \mathrm{~N}=72)$ containing shade type $(\beta=0.145,95 \%$ C.I. $0.007-0.283)$ as the significant explanatory variable. 
Table 2. Three component factors from PCA analysis regressed against \% trap success. Factor 1 was the only significant factor.

\begin{tabular}{|c|c|c|c|c|c|c|c|c|c|c|c|c|}
\hline & $\begin{array}{l}\text { Flood } \\
\text { Period }\end{array}$ & $\begin{array}{l}\text { Number } \\
\text { Adult HS }\end{array}$ & $\begin{array}{l}\text { Number } \\
\text { Exotic spp }\end{array}$ & $\begin{array}{l}\text { Shade } \\
\text { Type }\end{array}$ & $\begin{array}{l}\text { Shade } \\
\text { Amount }\end{array}$ & $\begin{array}{l}\text { Avg \#D } \\
\text { Veg spp }\end{array}$ & $\begin{array}{l}\text { \# Squares } \\
\text { w Forb spp }\end{array}$ & $\begin{array}{l}\text { \# Native } \\
\text { Shrub spp }\end{array}$ & $\begin{array}{l}\text { \# Squares } \\
\text { w Sedge spp }\end{array}$ & $\begin{array}{l}\text { Avg \#D } \\
\text { Grass spp }\end{array}$ & $\begin{array}{l}\text { \# Exotic } \\
\text { Vine spp }\end{array}$ & $\begin{array}{l}\text { \# Native } \\
\text { TSS spp }\end{array}$ \\
\hline Factor 1 & -0.867 & $\underline{0.796}$ & 0.060 & $\underline{0.930}$ & $\underline{0.872}$ & -0.032 & 0.560 & -0.072 & -0.457 & -0.086 & -0.077 & -0.383 \\
\hline Factor 2 & $\overline{0.205}$ & $-\overline{-0.012}$ & 0.409 & $-\overline{0.195}$ & $-\overline{-0.077}$ & $\underline{0.791}$ & $\overline{0.480}$ & 0.302 & 0.674 & $\underline{0.773}$ & -0.320 & $\underline{0.569}$ \\
\hline Factor 3 & 0.014 & -0.127 & $\underline{0.781}$ & -0.014 & 0.082 & $-\overline{0.105}$ & 0.308 & $\underline{0.683}$ & $\overline{0.279}$ & $\overline{0.158}$ & $\underline{0.761}$ & $\overline{0.228}$ \\
\hline
\end{tabular}




\section{DISCUSSION}

This study demonstrates the ability of white-footed mice to effectively identify and use habitat elements present in this heavily invaded and structurally altered forest. This population of mice chose to spend more time within the honeysuckle patch, likely for the greater protection from predators offered by the honeysuckle canopy cover. This concurs with the results of other studies of $P$. leucopus anti-predatory behavior in relation to Amur honeysuckle patches (Mattos and Orrock 2010; Dutra et al. 2011). In this study, the abundance of plants other than honeysuckle within the patch was lower than in the neighboring floodplain area, indicating a potential decrease in foraging options.

Peromyscus leucopus could be compensating for this by consuming more invertebrates (Anderson and Folke 1993; Whittaker 1966). White-footed mice could also maintain nesting sites within the relatively protected honeysuckle area, while primarily foraging in the denser vegetation along the edge of the patch. Meiners (2007) showed greater depletion of the seed bank under the honeysuckle canopy due to increased foraging effort, and Orrock et al. (2010) postulated this kind of effect could enhance the competitive advantage of honeysuckle. They could also be consuming honeysuckle berries (Rose $e t$ al. 2014), even though they are a low quality food source (Ingold and Craycraft 1983).

White-footed mice in this study were infrequently captured in floodplain sites, which had no honeysuckle canopy. In contrast to an earlier study (Batzli 1977), there was not enough connectivity over the floodplain for mice to move arboreally and thus avoid traps there, which suggests the low number of captures in the floodplain reflects a tendency in 
this $P$. leucopus population to avoid floodplain habitat. The potential avoidance of the floodplain cannot be completely explained by the decrease in canopy cover and the resulting loss of its protection against predators without further study. Increasing abundance of forb species also contributed to explanations of white-footed mouse distribution, but forb abundance is highest on the flood plain. The narrow band of vegetation between the floodplain and honeysuckle patch may constitute a narrow edge ecotone, potentially favored by mice for foraging excursions but not residence. These mice may select for honeysuckle patch habitat nearer areas of higher forb diversity within this ecotone, if the foraging provides a great enough benefit to be worth the increased predation risk. This scenario suggests that the honeysuckle canopy and vegetative variables are interacting in complex ways, working to create subtle patterns not revealed in this analysis.

One interesting possibility for how white-footed mice view the flood plain involves the increased abundance of invasive species in the ground layer. White-footed mice may tend to avoid areas where the ground layer contains a higher number of invasive species as Edalgo et al. (2009) found, although the novelty of invasive species should decrease rapidly with multiple generations. Generations of mice born after the colonization of an invasive plant should not necessarily recognize that plant species as out of place; if they do, it may suggest some passage of information across generations, or some other unknown mechanism letting them know a species does not belong. 
The high degree of variation within and between variables is also evident in the regression results. Regression analysis using the PCA factors as explanatory variables was significant $(p$-value $=0.023$ ) and thus demonstrated that these factors did explain the variation in capture success. However, this analysis produced a low $\mathrm{r}^{2}$ of only 0.058 , showing that a very large amount of the variation remained unexplained and thus that the PCA axes were poor predictors of mouse capture. I also regressed the most significant variable on each of the three factors against trap success in a separate analysis, which again yielded a low $\mathrm{r}^{2}$ value $(0.045)$ that was highly significant $(\mathrm{p}=0.009)$. These similar results suggest that while the explanatory variable does have some predictive power for the response variable, there is still a great deal of variation that lessens predictive accuracy.

Although I confirmed my primary hypothesis that white-footed mice would be found primarily under the Amur honeysuckle canopy, this initial experiment has led to more questions than answers. This study has supported earlier studies showing that whitefooted mice are strong generalists that can survive in almost any habitat (Adler and Wilson 1987) and that Amur honeysuckle is a dominant shrub that alters the plant community profile (Hartman and McCarthy 2008). Neither vegetative diversity nor abundance affected capture success. While Planz and Kirkland (1992) showed CWD to be heavily selected for in P. leucopus path selection, Anderson et al. (2003) showed increased complexity of ground vegetation, especially along the edge, led to increased $P$. leucopus abundance. However, in this study CWD similarly did not have a significant effect on capture success, a finding that conflicts with results from other studies, which 
have shown that CWD is an important determinant of microhabitat selection in $P$. leucopus (Greenberg 2002), and that it provides both foraging opportunities and cover (Drickamer 1990; Edalgo et al. 2009; Jones and Lindquist 2012).

This study reveals several dimensions of habitat use worthy of further study. This population of mice seems to prefer the honeysuckle-dominated area; however, there is still a great deal of variation in habitat selection that remains unexplained. There are also questions on the distribution of foraging resources, and how white-footed mice utilize the floodplain areas. This study examined general patterns of vegetation across quadrats, a more macroscale approach. The lower resolution within the data may have hidden some nuances of the habitat.

Focusing on areas dominated by honeysuckle may reveal stronger, more predictable patterns of habitat use within this preferred habitat type (Shields et al. 2014). Another question that arises along with consideration of habitat used by these mice is arboreal movement. Peromyscus leucopus are known to be semi-arboreal (Batzli 1977), and honeysuckle shrubs provide both increased stem density and a dense, contiguous canopy for movement. How often and under what conditions white-footed mice use the canopy habitat could help answer questions about their population distribution on the ground. Testing basic assumptions of foraging behavior can reveal if the resources available under the honeysuckle canopy are on par with those in the more densely vegetated floodplain area, or if basic predator-aversive behaviors are more dominant. 


\section{CHAPTER 2}

\section{FACTORS AFFECTING WHITE-FOOTED MOUSE (PEROMYSCUS LEUCOPUS) HABITAT SELECTION IN AN URBAN FOREST}

\section{INTRODUCTION}

Introductions of non-native, invasive plant species have significantly negatively affected biodiversity in the US (Gordon 1998; Wilcove et al. 1998) and around the world, especially in urban areas (McKinney 2006; Lambdon et al. 2008; McKinney 2008).

Invasive plant species alter their environment and ecosystem processes, disturbing urban plant communities (Gordon 1998; Pennington et al. 2010). Native small mammal species interact with invasive species as seed predators and dispersers (Manson and Stiles 1998; Williams 1999; Horncastle et al. 2004), potentially spreading invasive plants through caching (Abbott and Quink 1970; Orrock et al. 2010) and thus reducing native plant diversity (Collier et al. 2002; Gorchov and Trisel 2003). The ability of small mammals to use the microhabitat in and around areas experiencing plant invasion, and to use the invasive plants themselves, affects the likelihood of persistence for both the small mammals and native plants in urban ecosystems Small mammal species that persist within urban parks and green spaces are primarily generalists (Mahan and O'Connell 2005; Cavia et al. 2009). While ideal habitat for small mammals has high structural 
complexity, (Horvath et al. 2001), abundant woody debris (Fauteux et al. 2012; Kellner and Swihart 2014), and canopy cover (Zollner and Crane 2003), generalist species can work within their broad habitat preferences to best take advantage of available habitat components (Bellows et al. 2001). Flexibility in habitat requirements allows them to persist in often heavily disturbed, highly invaded urban parks. A major factor in small mammal habitat selection is mitigating predation risk through selection for cover (Brown 1988; Lima and Dill 1990; Brown and Kotler 2004; Hinkelman et al. 2012), though, this cover preference would likely still greatly influence small mammals. Understanding how specific invasive plants affect anti-predator behavior and microhabitat selection of small mammals helps to better understand the impact of invasive species. This knowledge also helps inform the likelihood of survival for species in the small mammal community.

Amur honeysuckle (Lonicera maackii; Rupr. Maxim.) is a common invasive shrub found in many urban ecosystems in the US (Luken and Thieret 1996; Hutchinson and Vankat 1998). Amur honeysuckle creates a dense canopy of vegetation (Hartman and McCarthy 2008) and reduces diversity and abundance of herbs, trees, and shrubs below its canopy through allelopathy and light competition (Deering and Vankat 1999; Collier et al. 2002; Miller and Gorchov 2004; Meiners 2007; Hartman and McCarthy 2008; McEwan et al. 2010). A single adult shrub can produce thousands of berries (Luken and Thieret 1996), though they have low nutritional quality (Ingold and Craycraft 1983).

The effects of this shrub on small mammals in urban parks are poorly understood. One component of some urban forests that can potentially affect small mammals is the 
presence of a dense shrub layer (Chupp et al. 2013) like that created by Amur honeysuckle (Collier et al. 2002; Hartman and McCarthy 2008). This strong canopy layer could be advantageous for small mammals in parks; however the reduced vegetative density may also reduce potential food resources.

This study concentrates on one generalist small mammal that persists within urban parks (Barko et al. 2003; Mahan and O'Connell 2005; Munshi-South 2012), the white-footed mouse (Peromyscus leисориs). White-footed mice demonstrate broad habitat tolerances which facilitate their survival in heavily altered sites (Bellows et al. 2001; Brannon 2005). Peromyscus leucopus readily uses disturbed habitats, selecting the best microhabitat available (Greenberg 2002; Jones and Lindquist 2012). This species also uses both the terrestrial and arboreal components of its habitat (Batzli 1977), potentially for foraging.

In non-urban areas invaded by Amur honeysuckle, Peromyscus leucopus is often the most populous small mammal by a large margin (Mattos and Orrock 2010; Dutra et al. 2011; Rose et al. 2014; Shields et al. 2014). White-footed mice seem to preferentially favor Amur honeysuckle shrub cover for foraging (Mattos and Orrock 2010; Dutra et al. 2011). In areas of Morrow's honeysuckle (Lonicera morrowii), a close relative of Amur honeysuckle, white-footed mice preferred microhabitat associated with a higher density of shrubs and shrub cover (Edalgo et al. 2009). However, P. leucopus do not favor $L$. maackii berries as food source in a natural forest (Rose et al. 2014), although they readily 
eat the berries in lab settings (Williams 1999, Williams et al. 1992). However, none of these studies examined habitat use within an urban park.

My primary objective in this study was to examine the relationship between white-footed mice and Amur honeysuckle canopy as it relates to honeysuckle phenology. My second objective was to explore microhabitat preferences within the small mammal community, focusing on white-footed mice distribution at a fine scale. I predicted that white-footed mice would preferentially favor the honeysuckle canopy when the bush is fully green but show no preference for berries. I also predicted that total plant species richness as well as invasive species richness would help determine microhabitat selection under the canopy.

\section{METHODS}

\section{Study Site}

The study site was Twin Parks, an urban park 4.9km from downtown Louisville, Kentucky and approximately 500m from the Ohio River. The bottomland Ash-Maple (Fraxinus-Acer) forest comprising this park covers 15.59 ha and receives little to no management. Amur honeysuckle shrubs occupy approximately $75 \%$ of the area of Twin

Parks (Appendix 1, Map 2), dominating the midcanopy layer where they occur. One main gravel path meanders halfway into this park, turning into two divergent dirt paths that experience regular usage by the public. A large windstorm in September 2008 and an ice storm in January 2009 damaged many trees in this park, creating much of the woody debris found on the study plot. 


\section{Focal Honeysuckle Shrubs}

I selected 26 adult honeysuckle shrubs with at least two stems, with the largest stem diameter at breast height $(\mathrm{dbh})$ at least $3 \mathrm{~cm}$, and all stems at least $1 \mathrm{~cm}$ in $\mathrm{dbh}$. These focal shrubs stood at least $15 \mathrm{~m}$ apart, and at least $15 \mathrm{~m}$ from the edge of the honeysuckle patch. The canopy of each shrub extended a minimum of $2.5 \mathrm{~m}$ from the center. I measured dbh of all stems on each shrub and determined whether each stem was living or dead. I also measured each visible root ball along the longest axis and the perpendicular axis in the same plane in order to generate an average visible root ball diameter. For each shrub, I measured crown height at its highest point, usually at or near the center of the crown. To calculate the depth of each focal shrub canopy, I measured distance from ground to the lowest point of the canopy and subtracted it from crown height. I visually estimated the \% cover of each canopy within a radius of $2.5 \mathrm{~m}$ from the center of the shrub. To do so, I used flags and string to mark a circle (radius $=2.5 \mathrm{~m}$ ) centered on the base of the focal shrub and assessed shrub canopy cover from underneath between 12:0013:00 hrs on sunny, summer days.

\section{Trapping}

I placed four Sherman traps $(8.5 \mathrm{~cm}$ x $8.0 \mathrm{~cm} \times 23.2 \mathrm{~cm})$ around each shrub. Two traps were placed on the ground, and two traps were placed in the shrub canopy. I placed one ground trap (base) directly adjacent to the base of the focal shrub. I placed the second ground trap (away) $1-2.5 \mathrm{~m}$ from the base of the focal shrub and adjacent to coarse woody debris, large fallen logs, and/or dense snags. I secured Sherman traps to the ground with two metal staples formed from 10-gauge fencing wire to help limit disturbance from northern raccoons (Procyon lotor). 
I used polyfilament twine to tie two $15 \mathrm{~cm}$ x $2.5 \mathrm{~cm}$ pieces of $1 \mathrm{~cm}$ thick particleboard into the canopies of each focal honeysuckle shrub to create platforms for arboreal traps. All platforms were placed so that a stem ran along at least one edge of the platform, allowing mice access. Platforms were tied so as to allow for natural movement of the shrub in wind while maintaining platform stability. I placed one Sherman trap on each platform and secured it with two crossed 12 " nylon elastic cords.

To reduce disturbance of the Sherman traps by larger mammals, I also set out eight raccoon-sized $(19 \mathrm{~cm} \times 20 \mathrm{~cm}$ x $51 \mathrm{~cm})$ and 10 squirrel-sized $(31 \mathrm{~cm}$ x $26 \mathrm{~cm}$ x $82 \mathrm{~cm})$ Tomahawk traps near focal honeysuckle shrubs experiencing routine (multiple consecutive nights) disturbance during the first and second trapping sessions. By the end of these two sessions, no shrubs with just Sherman traps experienced routine disturbance. These traps were at distances of $1.5-3 \mathrm{~m}$ from a focal shrub and at least $1.5 \mathrm{~m}$ from any Sherman trap. Disturbance was quantified as the number of traps that were pulled off platforms or pulled out of the metal staples, or that had chewing damage on the elastic tethers. Tomahawk traps reduced disturbance from eastern grey squirrels (Sciurus carolinensis), Virginia opossums (Didelphis virginianus), and northern raccoons by capturing these animals before they could disturb traps.

Trapping sessions occurred in October 2013, and March-July and September 2014. Each trapping session was designed to consist of two nights of trap conditioning followed by four consecutive trap nights. Trap conditioning involved setting out all traps two nights 
prior to the start of trapping, propping them open, and adding wool if nighttime temperatures were expected to drop below $40^{\circ} \mathrm{F}$. On the first day of trapping, all traps were baited with a mixture of peanut butter and oats (Yunger 2002; Edalgo and Anderson 2007) and were rebaited each morning, during the process of checking all traps. Twice trapping sessions were ended after two nights due to intense rain. Three times trapping sessions were ended after three nights in an effort to reduce potential stress on the $P$. leucopus population. In fair weather, the decision to end a trapping session after three rather than four nights was predicated on the number of mice recaptured multiple times during a session, and the overall condition of recaptured mice. When $80 \%$ of animals assessed on a given morning were recaptures from that session, I stopped trapping. On a given morning, if more than five mice had also been captured on the previous night, or more than two mice had also been captured both of the previous two nights, the likelihood of an individual mouse dying was considered large enough to end trapping.

I measured the hind foot, ear, tail, and body length (tip of rostrum to base of tail) of each small mammal captured, and also recorded its weight. Each individual was also identified to species, and its sex and reproductive condition were determined. Individuals were ear tagged using uniquely numbered Monel 1 tags (National Band \& Tag Co., Newport, Ky). Trap placement and shrub number were also recorded for each capture. Small mammal species captured in this study included white-footed mouse (Peromyscus leucopus), short-tailed shrew (Blarina brevicauda), eastern chipmunk (Tamias striatus), and southern flying squirrel (Glaucomys volans). Other mammals captured in Tomahawk traps were released upon discovery each morning. 


\section{Habitat Assessment}

I placed 26 survey grids of $5 \times 5 \mathrm{~m}$ so that a focal shrub was in the center grid square of each (Appendix 1, Map 2). Vegetation assessment took place on $101 \mathrm{~m}^{2}$ 'squares' in each survey grid. To select squares for assessment, I considered the $5 \mathrm{x} 5 \mathrm{~m}$ grid as two rings around a single central square. The inner ring consisted of 8 square meters and the outer ring consisted of 16 square meters. I assessed vegetation on the central square, as well as three squares randomly selected from the middle ring and six squares randomly selected from the outer ring.

Vegetation on each selected square was assessed by first identifying all species present on each square sampled, then counting number of individuals for each species. Each species was ranked 1,2 , or 3 on a dominance scale. The most dominant plant, based on a combination of size and cover, was ranked 1. Any plant species either tall enough or present in enough numbers to be visible without manipulating any vegetation was ranked 2. Any plant species whose members were either small enough, or present in low enough numbers, that manipulation of other vegetation was necessary to locate it was ranked 3. Grasses and sedges were not identified to species but were grouped into common 'grass' or 'sedge' categories.

When analyzing vegetation I only considered tree seedlings and saplings no more than 1.5 meters tall, as they were not a part of the canopy. All trees present on the surveyed squares were identified to species and their diameter at breast height (dbh) recorded. 
Once all data were collected for all plant species, plants were divided into functional groups: forbs, grasses, sedges, vines, shrubs, and tree seedlings. All invasive species were identified as such. Variables extracted for all sampled vegetation were also collected for each functional group.

I created gridded maps of each $5 \times 5 \mathrm{~m}$ plot to indicate location and size of all trees and honeysuckle. I drew all logs, and snags to scale on these maps, as well as all woody debris $>2 \mathrm{~cm}$ in diameter and $>1 \mathrm{~m}$ in length. I also created larger-scale maps that depicted areas of CWD, logs, snags, trees, and honeysuckle within a $15 \mathrm{~m}$ radius around each focal shrub.

I assessed leaf phenophase as budding, present, or absent for the focal shrub during each trapping session. Any berries present on the focal shrub were counted, and the percentage of green vs. red berries estimated. Color was quantified on a scale from $0-10$, with $0=0 \%$ red, $100 \%$ green to $10=100 \%$ red, $0 \%$ green. Percentages were estimated to the nearest $10 \%$ during the counting process.

\section{Honeysuckle Assessment}

I measured all adult and juvenile honeysuckle shrubs on the selected squares using the same method as for the focal shrubs. Shrubs were categorized as adults if they formed a part of the mid-level shrub canopy, had the majority of their stems growing outward instead of upwards, and had canopy-directed stems that were well branched. Juvenile shrubs were at least $60 \mathrm{~cm}$ in height and were usually multi-stemmed but had primary stems directed toward the canopy, with relatively few stems growing outward (Deering 
and Vankat 1999). Juvenile shrubs can produce berries if in a high light environment, so reproductive condition was not a measure of age class. Any honeysuckle shrubs less than $60 \mathrm{~cm}$ in height were categorized as seedlings during vegetative sampling and counted as such, but not measured.

All values for the sampled honeysuckle around each focal shrub were averaged for each measurement, producing means for adult and juvenile honeysuckle combined, as well as separate means for adults and for juveniles. Adults and juveniles were separated to evaluate their relative impact on the surrounding community. Adult honeysuckle shrubs generally grow at lower densities than juveniles, with higher canopies and less ground cover. Adults and juveniles were combined to test whether mice selected for overall density of honeysuckle with distinction between age classes, or if the differences in each age class made adults or juveniles more preferable.

\section{Environmental Data}

Weather data were gathered from The Weather Channel (2015) online archives to further determine the effects of the weather on capture success. I collected data for the 24-hour period preceding each capture day to represent the time of activity. Variables collected included minimum, maximum, and mean temperature; dew point; precipitation; and \% moonlight.

\section{Human Presence at Focal Shrubs}

I quantified human presence (not including my own) on each focal shrub sampling grid on a scale of 0 - 10. A score of 0 indicated an extremely small chance of human presence and 10 indicated the presence of an encampment used for extended periods daily. Values 
8 - 10 were within $10 \mathrm{~m}, 5 \mathrm{~m}$, and $2 \mathrm{~m}$ of a camp; 5 - 7 were within $10 \mathrm{~m}, 5 \mathrm{~m}$, and $2 \mathrm{~m}$ of the regularly used path; 2 - 4 were within $10 \mathrm{~m}, 5 \mathrm{~m}$, and $2 \mathrm{~m}$ of an area where people rarely occur; 1 was an area that may experience human presence although none was witnessed in this study; and 0 was an area with no evidence of human visitors and a low probability of human presence. I estimated levels of human presence based on trends observed over 3.5 years of year-round research activity at this site, and observational data gathered during the time of this study.

\section{Statistical Analysis}

\section{Berry and Leaf Condition}

I performed a chi-square analysis of berry and leaf condition versus capture location. Combinations of berry and leaf status included: berries and leaves both absent (March 31-April 1 2014), berries absent and leaves present (May 13-14, June 12-14, July 23-25, July 29-31 2014), and berries and leaves both present (October 1-4, 2013; September 2326 2014). Chi-square analyses were run using these three combinations of berry and leaf presence/absence against numbers of arboreal and ground captures. Due to low numbers of captures, I combined captures at the base of honeysuckle shrubs with captures $1-2.5$ m away from a honeysuckle shrub into one category, ground captures.

\section{Identification of Significant Habitat Factors}

I used correlation tables to identify highly correlated explanatory variables for the purpose of removing non-independent variables. When multiple non-independent explanatory variables were significantly correlated with the each other, I selected for retention the independent variable (IV) with the lower p-value score in relation to the 
dependent variable (DV). If both IV's were significant at to the same level (i.e. $<0.05,<$ 0.01 ), then I kept the IV with the higher $\mathrm{r}^{2}$ correlation with the DV for further analysis. Those variables left were entered into a Principal Component Analysis.

I identified those variables best able to explain the variation in my dependent variable using Principal Components Analysis in SPSS (IBM SPSS Statistics v. 21.0). I also used PCA to identify the relationship between variables through analysis of the component axes. All selected variables were entered into the initial PCA, and variables with communality under 0.500 were removed from the analysis (Novčić et al. 2012). A new PCA was run with the reduced variables, and PCAs were run until no more variables fit conditions for removal. I kept only component axes with eigenvalues $>1$ (Kaiser-Guttman criterion; Jackson 1993).

Component scores for the four PCA axes were regressed against the two dependent variables $P$. leucopus captures and shrub number using SPSS. Stepwise regression was used to elucidate factors explaining variation in $P$. leucopus captures as a measure of population distribution, and variation in small mammal species richness. A stepwise regression was also used to determine what factor explained variation among sampled shrubs. By determining if the factors controlling variation across sampled sites are the same or different from the variables explaining population distribution and variation in species richness, we can determine the relative importance of the independent variables. If a variable that is significant to $P$. leucopus capture does not differ significantly between shrubs, then that variable must have some increased importance. 


\section{RESULTS}

\section{Capture and Vegetation Statistics}

A total of 132 captures of 55 White-footed Mice occurred over 2,184 trap nights during the course of this mark-recapture study. Thirty males and 25 females were captured, and a total of 65 captures were included in the analysis. For individuals captured multiple times during the same berry/leaf condition, I only kept the first capture for use in analyses. Ten individuals were captured during two differing berry/leaf conditions, and the first capture from each of the berry/leaf conditions was used. Capture numbers and trap success varied by seasons, which were defined by leaf/berry phenology (Table 3). The other small mammal species that were captured included five eastern chipmunks, one southern flying squirrel, and seven short-tailed shrews. These species were not considered in individual analyses due to the low capture numbers

A total of 41 different plant species were identified during this study, including eight invasive species (four forbs, three vine species and one shrub species). The plant species included 21 forb species, eight vine species, four shrub species, and eight tree species. All grasses were grouped and all sedges were grouped.

\section{Factor Characteristics}

The final principle component analysis (PCA) revealed four axes with an eigenvalue $>1$, explaining $77.54 \%$ of the variation. Urban variables invasive spp. richness (0.890) and human presence $(0.725)$ dominated the first factor, which explained $27.42 \%$ of the variation (Table 4). The second factor explained $19.64 \%$ of the variation, and revealed 
an inverse relationship between tree abundance $(0.782)$ and abundance of ground layer vegetation (-0.866). An inverse relationship between honeysuckle seedling abundance (0.867) and percent coverage of the honeysuckle canopy (0.707) dominated factor 3 as well, which had $15.87 \%$ explanatory power. Factor 4 included predominantly CWD abundance (0.907), supported by adult honeysuckle abundance $(0.563)$, at $14.56 \%$. The eight variables identified as important across the four axes withal had component score loading $>0.500$.

\section{Honeysuckle Phenology and P. leucopus Captures}

Mice were more likely to be captured in ground traps than in arboreal traps under all phenological conditions, a pattern that was particularly marked when neither berries nor leaves were present $\left(\chi^{2}=35.85, p=<0.001, \mathrm{df}=2\right.$; Table 3$)$. Overall numbers of captures suggested that mice may have been more active than expected when both leaves and berries were present, and less active than expected when only leaves were present.

Table 3. Trapping Sessions based on presence/absence of berries and leaves. Represented are relative trap success and (\# captures) for each of the three trap locations, with ground representing base + away. Each of the three sampled berry/leaf combinations is represented; no trapping took place when berries were present and leaves were absent.

\begin{tabular}{llllll}
\hline \multirow{2}{*}{ Berries } & \multirow{2}{*}{ Leaves } & \multicolumn{3}{c}{ Arboreal } & \multicolumn{2}{l}{ Ground } \\
& & Obs & Exp & Obs & Exp \\
\hline Yes & yes & 11 & 12 & 14 & 12 \\
No & yes & 11 & 17 & 15 & 17 \\
No & No & 1 & 3 & 13 & 3 \\
$\chi$-square & 35.845 & & & & \\
P-value & $<0.001$ & & & & \\
\hline
\end{tabular}




\section{CWD and Urban Relevance}

Regressing the four factors against shrub number revealed that variation across shrubs is a result of predominantly urban factors human presence and invasive species richness (factor 1 , adjusted $\mathrm{r}^{2}=0.30, p=0.002, \mathrm{~N}=26$; Table 4). This result suggests a gradient for these two variables from shrubs with low numbers near the trails to higher-numbered shrubs nearer the opposite end of the park.

Peromyscus leucopus abundance was reliant on CWD abundance, and to a lesser extent adult honeysuckle abundance (factor 4 , adjusted $\mathrm{r}^{2}=0.15, p=0.028, \mathrm{~N}=26$; Table 5). Human presence and invasive spp. abundance (factor $1, \mathrm{p}=0.08$ ) was marginally significant in explaining distribution of white-footed mice.

\section{Environmental Variables}

Weather variables were analyzed using a PCA to reduce the number of explanatory variables, followed by a stepwise regression to determine significance. These variables were analyzed separately from other variables because they were recorded for each sampling date and represented the entire study plot, in contrast to the other variables, which were plot-based and covered multiple days. Of the initial seven weather-based variables, correlation analysis revealed the four temperature-based variables were all highly correlated, with dewpoint having the highest explanatory ability for both P. leucopus captures and all small mammal captures. For P. leucopus captures, the PCA analysis created one factor with dewpoint, total precipitation, and percent moonlight that explained $52.46 \%$ of the variance. The stepwise regression created a model using only dewpoint (adjusted $\mathrm{r}^{2}=0.27, p=0.010, \mathrm{~N}=21$ ). 
TABLE 4. Four component factors from PCA analysis regressed against $P$. leucopus trap success. Factor 4 was the only significant factor.

\begin{tabular}{|c|c|c|c|c|c|c|c|c|}
\hline & $\begin{array}{l}\text { Number } \\
\text { Sq/Spp }\end{array}$ & $\begin{array}{l}\text { Number } \\
\text { Trees }\end{array}$ & $\begin{array}{l}\text { Number } \\
\text { Seedling HS }\end{array}$ & $\begin{array}{l}\text { Number } \\
\text { Sq w CWD }\end{array}$ & $\begin{array}{l}\text { HS } \\
\text { Canopy }\end{array}$ & $\begin{array}{l}\text { Human } \\
\text { Presence }\end{array}$ & $\begin{array}{l}\text { Number } \\
\text { Invasive spp }\end{array}$ & $\begin{array}{l}\text { Number } \\
\text { Adult HS }\end{array}$ \\
\hline Factor 1 & -0.174 & -0.202 & -0.192 & -0.198 & -0.357 & 0.752 & 0.890 & 0.692 \\
\hline Factor 2 & -0.866 & 0.782 & 0.028 & -0.098 & 0.235 & $-\overline{-0.048}$ & $\overline{0.010}$ & $\overline{0.037}$ \\
\hline Factor 3 & 0.083 & $-\overline{-0.024}$ & 0.867 & -0.057 & -0.707 & -0.178 & 0.113 & 0.232 \\
\hline Factor 4 & -0.078 & -0.174 & $\overline{0.134}$ & 0.907 & 0.253 & -0.101 & -0.175 & 0.563 \\
\hline
\end{tabular}


TABLE 5. Stepwise Regression models using a) Shrub \# and P. leucopus Captures as dependent variables regressed against PCA component scores, and b) P. leucopus captures regressed against weather data by sampling day.

a)

D. Variable

I. Variable

Shrub

Factor 1

P. leucopus captures

Factor 4

0.153

Model

adjusted $\mathrm{R}^{2} \mathrm{SE}$

0.301

6.396

1.523

12.762

5.499

0.028

\section{ANOVA}

SS

480.564

11.746

0.002 b.)

D. Variable

Model

I. Variable

P. leucopus Captures

Dewpoint adjusted $\mathrm{R}^{2} \mathrm{SE}$

0.266
2.086

\section{ANOVA}

SS F

$\mathrm{P}$

35.866
0.010

\section{DISCUSSION}

On this site, Peromyscus leucopus stayed true to their general habitat preferences, selecting for habitat that provided greater predator protection. White-footed mice greatly preferred foraging on the ground when there was no Amur honeysuckle canopy cover, selecting for areas with more coarse woody debris (CWD). Areas of higher relative CWD provide protection from predators on the ground as well as foraging opportunities. They also preferred areas with more adult honeysuckle; when canopy cover is present, honeysuckle shrubs provide both foraging opportunities and movement pathways. 
When canopy cover was present, white-footed mice used the honeysuckle canopy nearly as much as the ground, but this study showed no selective preference for the canopy when berries were present. This indicates that $P$. leucopus is likely not actively seeking out honeysuckle berries as a food source. Other attractive foraging options for $P$. leucopus are present in the canopy, in the form of bird's nests (Borgmann and Rodewald 2004). Nests in honeysuckle shrubs tend to be lower to the ground and more exposed to predators (Schmidt and Whelan 1999; Schmidt et al. 2001; Borgmann and Rodewald 2004), and eggs and young chicks serve as a ready protein source. The increased stem density from the shrubs would also provide greater access to trees for fruits and nuts, as well as access to suspended CWD.

Arboreal movement through the shrub canopy would also likely help limit detection from terrestrial predators such as the Northern raccoon Procyon lotor, who are in general too large to easily climb into the canopy of all but the largest honeysuckle shrubs. The canopy would also likely provide a more constant enshrouding to limit sight detection as well. White-footed mice have demonstrated a propensity to use shrub and tree canopy for movement especially on floodplains (Batlzi 1977). Twin Parks floods regularly, and although the majority of shrubs are not inundated, they do provide a high degree of connectivity along the edges and into floodplain trees.

\section{Inherently ‘Urban' versus 'Natural' Factors}

This study revealed that two of the three factors explaining variation in trap success across the sampled shrubs were inherently urban; human presence, and invasive species richness. These two factors also go hand in hand, as it is likely that disturbance resulting 
from human presence helps invasive species establish, and creates the habitat used by birds and other seed dispersers that introduce and help spread the exotic species. Adult honeysuckle abundance was highest in those areas experiencing intermediate levels of human presence, with more juveniles in areas of greater presence, and fewer, more mature, adult honeysuckle in those areas with little to no human presence.

White-footed mice were trapped more often in areas with greater CWD abundance and higher adult honeysuckle abundance. This pattern of habitat use, favoring areas with more CWD and adult honeysuckle, is consistent with the documented behavior of whitefooted mice (Fauteux et al. 2012; Kellner and Swihart 2014). Peromyscus leucopus also avoided those areas with greater invasive species richness and human presence Edalgo et al. (2009) found that $P$. leucopus appear to avoid areas with higher invasive species richness, which probably played a larger role than the presence of humans. White-footed mice generally chose to move through areas with high structural complexity, and this is provided by the CWD present around all shrubs as well as the shrub canopy. Whitefooted mice also have shown a proclivity for avoiding areas with more dense herbaceous vegetation (Pearson et al. 2001; Edalgo et al. 2009), and the presence of unknown exotic species in the ground layer may enhance this effect (Edalgo et al. 2009).

White-footed mice are strong habitat generalists and readily use the honeysuckledominated features of this park; however, they also tend to avoid those more heavily disturbed and invaded areas. The honeysuckle enters into both parts of this dynamic, as they provide an important structural component and simultaneously are a dominant 
invasive species that may preclude other species from an area. It is the increasing abundance of invasive species in the ground layer that seems to affect white-footed mice, likely a result of potential forage becoming more unfamiliar. Amur honeysuckle shrubs are only one species, even if highly dominant, and with the exception of seedlings are not part of the ground layer. The benefits provided by the honeysuckle shrub canopy, along with the majority concentration of CWD occurring under the canopy, seem to outweigh the distrust white-footed mice display for areas with a high percentage of invasive species.

\section{Environmental Factors}

The only environmental variable that stood out as important for white-footed mice was dewpoint: captures tended to increase when dewpoint was lower. A lower dewpoint generally indicates lower humidity and/or lower air temperatures. Both of these factors can help explain the increase in captures. Dewpoints were lowest during March and April, when the abundance of resources in the environment was relatively low. Whitefooted mice would be more likely to take advantage of the food resources in the traps during these conditions. Through the summer and fall, a lower dewpoint would indicate lower humidity, which decreases thermoregulatory costs. If individuals are able to more easily regulate their body temperature, they will tend to move more widely and be more likely to encounter a trap.

\section{Management Implications}

Urban ecosystems are known for the high level of exotic and invasive species present in the remaining green spaces. If hardy generalist species like $P$. leucopus select away from 
habitats with higher invasive species diversity, this may suggest at least an increased stress or at most a selection away from certain types of habitats, where a high percentage of the community is invasive species. This trend supports restoration practices designed to minimize or eliminate invasive plants while simultaneously promoting native species. By encouraging native plant communities in urban areas, we can help ensure populations of small mammals are fully using the habitat.

The shrub honeysuckle itself was also of interest in this study, as P. leucopus does appear to use the shrub canopy, and in general selected for areas of more adult shrubs. This preference for honeysuckle shows this shrub can fulfill some habitat requirements of $P$. leucopus, primarily through the dense shrub canopy. Although Amur honeysuckle is just one species, it is a dominant invasive shrub that tends to have more invasive plants growing under it. White-footed mice selectively chose the best habitat under the canopy based on the presence of native species and CWD, but if no invasive plants were present, perhaps the other small mammal species that were in so low an abundance might have larger, more stable populations. Removal of this shrub does not seem to have any major long-term implications for P. leucopus populations (Shields et al. 2014), but the effect of such a large scale disturbance event on the other species present would need further analysis.

\section{Conclusions and future directions}

This study revealed important microhabitat preferences of white-footed mice in the Amur honeysuckle patch. The mice maintain an apparent preference for CWD while also using the honeysuckle canopy as cover. Further study into canopy foraging by this small 
mammal may help determine the role of white-footed mice in songbird egg predation, and answer questions about available and utilized canopy resources. This study also pointed toward a potential intolerance by white-footed mice of increasing invasive species abundance as well, which bears further research and study. A potential threshold intolerance or gradient of avoidance for such a strong habitat generalist as $P$. leucopus suggests most other small mammal species would also likely be affected. The relationship between the overall abundance of ground layer vegetation in relation to invasive species abundance would also be an important factor to determine. 


\section{CHAPTER 3}

\section{MOONLIGHT AND HABITAT TYPE AFFECT PERCEIVED PREDATION RISK IN WHITE-FOOTED MICE (PEROMYSCUS LEUCOPUS)}

\section{INTRODUCTION}

Increased predation risk ranks as one of the largest costs associated with foraging in small mammals (Brown and Kotler 2004; Preisser et al. 2005; Creel and Christianson 2008). One common metric used to assess individuals' perception of predation risk is giving up density (Brown 1988; Brown 1992). Giving-up density (GUD), which is the density of resources remaining when a forager leaves a patch, provides a measure of relative foraging cost as assessed by the forager. The marginal value theorem (Schoener 1971; Charnov 1976) predicts that as the pool of available resources in a patch diminishes, the value of continuing to forage in the patch diminishes as well (Schmidt et al. 1998; Schmidt 2000). Thus, a higher GUD at a given patch suggests that the perceived cost of foraging there is also high.

Giving-up density is affected by abundance of resource patches, metabolic cost of foraging, relative patch yield, and factors that alter the risk of predation. In general, 
foragers have lower GUDs when patches are scarce, environmental conditions exert a lower metabolic cost, the available resource provides a relatively high per-unit gain, and perceived predation risk is low (Bedoya-Perez et al. 2013). For small mammals, the presence of microhabitat features such as canopy cover, woody debris, and vegetative cover provides greater protection from predators and lowers the risk of detection (Adler and Wilson 1987; Brown et al. 1988; Greenberg 2002; Bakker 2006; Hodson et al. 2010). These features also influence foraging behavior, resulting in lower GUDs (Planz and Kirkland 1992; Orrock et al. 2004; Wolf and Batzli 2004; Mattos and Orrock 2010; Hinkelman et al. 2012).

Similarly, light levels affect predation risk, and as a result foragers alter GUD depending on cloud cover (Orrock and Danielson 2009; Dutra et al. 2011) and lunar cycles (Zollner and Lima 1999; Mattos and Orrock 2010). Foraging activity levels tend to increase and selection for ground or canopy cover can relax when cloud cover is greater (Kotler et al. 1993; Mattos and Orrock 2010) and moon illumination is less (Bowers 1990; Brillhart and Kaufman 1991), resulting in lower GUDs in riskier habitats. Alterations to environmental cues such as light level and cover can impose a greater effect on foraging behavior and predation threat perception than direct predation cues (Kotler et al. 1994; Orrock et al. 2004; Orrock and Danielson 2009).

This study examines factors that affect giving-up density in the white-footed mouse Peromyscus leucopus (Rafinesque 1818) in an urban park. Peromyscus leucopus is a generalist species (Batzli 1977; Adler and Wilson 1987; Brannon 2005) that readily 
tolerates habitat disturbance (Adler and Wilson 1987) and thus often persists in urban landscapes (Barko et al. 2003; Jones and Lindquist 2012; Munshi-South 2012). Whitefooted mice can alter foraging behavior and habitat selection in response to habitat or patch-level changes in the vegetative community and structure (Mattos and Orrock 2010; Kellner and Swihart 2014). Peromyscus leucopus makes a good target species due to the large body of knowledge regarding habitat selection (Drickamer 1990; Bellows et al. 2001; Brannon 2005), demography (Adler and Wilson 1987; Eagan et al. 2011), foraging behavior (Bowers and Dooley 1993; Fanson 2010), diet (Whittaker 1966; Rose et al. 2014), path selection (Barnum et al. 1992; McMillan and Kaufman 1995), and urban ecology (Barko et al. 2003; Chupp et al. 2013). White-footed mice are also a common focal species for GUD studies (Bowers and Dooley 1993; Schmidt and Ostfeld 2003; Shaner et al. 2007).

The effect of the urban environment on predation risk assessment is not well known in small mammals (but see Harmon et al. 2005; van der Merwe et al. 2007; Lemaître et al. 2010). However, several features of urban habitats are likely to affect GUD. For example, in cities, habitats are often highly altered and experience loss of many native species (Hobbs 1988; Jenerette and Wu 2001; Pennington et al. 2010). Urban plant communities are heavily altered by invasive plant species (Godefroid 2001; Loeb 2006; Chytry et al. 2008) that change the abundance, distribution, and kind of both coarse woody debris and food resources. These and other changes likely affect small-mammal behavior, in ways we are just beginning to understand (Crooks 2002; Dutra et al 2011; Johnson and De Leon 2015). Predator abundance and diversity are also altered in urban ecosystems 
(Hoffmann and Gottschang 1977; Smith and Engeman 2002; Bateman and Fleming 2012). While urban ecosystems in general are considered to experience an overall decrease in predators (Crooks 2002; Shochat et al. 2010; Pickett et al. 2011), some few mammalian predators have learned to use the urban matrix and fragments therein (Pickett et al. 2011; Bateman and Fleming 2012) and may reach much higher densities than in non-urban habitats (Hoffmann and Gottschang 1977; Smith and Engeman 2002; Bateman 2012). Finally, abiotic impacts of urbanization, such as ecological light pollution (Longcore and Rich 2004) and the urban heat island effect (Oke 1982), likely also affect white-footed mouse behavior.

This study also examines the potential role of the invasive shrub Amur honeysuckle (Lonicera maackii; Rupr. Maxim.) in mediating anti-predator behavior. Lonicera maackii suppresses the vegetative community in which it establishes (Collier et al. 2002; Gorchov and Trisel 2003; Miller and Gorchov 2004; McEwan et al. 2010), and its canopy dominates the shrub layer (Hartman and McCarthy 2008). Mattos and Orrock (2010) and Dutra et al. (2011) worked in the same wildlife conservation forest to show that $P$. leucopus preferentially foraged under L. maackii canopy as a response to potential predators. The effect this shrub would have on white-footed mice in a more heavily disturbed urban park is not known.

In this study, I investigated how the presence of L. maackii and coarse woody debris (CWD; defined as sticks and dead woody vines $>4 \mathrm{~cm}$ in diameter and $>1 \mathrm{~m}$ in length, tree snags, and fallen logs) affected GUD in white-footed mice. I also assessed the effect 
of environmental variables, including temperature, humidity, cloud cover, and moonlight, on GUD. I predicted white-footed mice would forage to lower GUDs in areas of greater cover from Amur honeysuckle, and in the presence of cover in the form of CWD. I predicted white-footed mice would forage to lower densities when moon illumination is least, but that this effect would be less pronounced under the honeysuckle canopy.

\section{METHODS}

\section{Study site}

The study took place in 2014 in Louisville, Kentucky in Twin Parks (38 $16^{\prime} 51.88^{\prime \prime} \mathrm{N}$, $\left.85^{\circ} 41^{\prime} 29.46^{\prime \prime} \mathrm{W}\right)$, a 15.6 ha urban park that receives little to no city maintenance (e.g. mowing, tree trimming, brush clearing etc.). The habitat is bottomland floodplain forest of ash-maple (Fraxinus-Acer) composition. Lonicera maackii dominates the understory in this park, except in two small floodplains that preclude L. maackii spreading over the entire area (Predick and Turner 2008). Severe wind and ice storms in 2008 and 2009 created abundant coarse woody debris and snags within the park. Sampling took place over four trial periods, which were June 16 - 18, July 15 - 17, September 12 - 16, and

October 30 - November 3. The moon was in the waning gibbous phase for dates sampled in June, July, and September (between $46 \%$ and $87 \%$ full), but in waxing gibbous phase for the dates in October-November (between $43 \%$ and $85 \%$ full).

This experiment used 18 stations, with six replicate stations sampled in each of three habitat types. Each station included two containers for GUD assessment, one with CWD present and one with CWD absent, for an overall total of 36 containers. Stations were 
placed 12 to $15 \mathrm{~m}$ apart from each other, and the two containers at each station were 1.0 to $2.5 \mathrm{~m}$ apart. The three habitat types included interior, (i.e., within a honeysuckle patch and $>15 \mathrm{~m}$ from its edge); edge, (the margin of the honeysuckle patch); and open (>10 m from the edge of the honeysuckle patch and outside the patch on the flood plain). All containers in the interior and edge of the honeysuckle patch were directly under honeysuckle shrub canopy cover. All containers along the open flood plain had tree cover but no shrub cover. Those containers with CWD present were placed within naturally occurring coarse woody debris, and were covered on at least two sides and the top by sticks $>1 \mathrm{~m}$ long and $>2.5 \mathrm{~cm}$ in diameter.

I used six replicates for each of the six possible combinations of habitat and cover to evaluate any habitat effects on risk-aversive behavior. The microhabitat available for selection within each of the three habitat types, aside from CWD presence or absence, was assumed to be relatively consistent. Based on this assumption, variation in GUD for the six containers within a particular combination of habitat and CWD cover can be directly attributed to differences in predator risk perception within that microhabitat rather than potential differences in foraging cost (Brown 1988). The same concept holds true for sampling across multiple temporal variables. Variation across sampling nights for the six containers within a particular combination of habitat and CWD cover can be attributed to differences in the perception of risk across the range of days sampled, rather than differences in the habitat. 
Habitat assessment for each of the 36 containers took place within a $2 \times 2 \mathrm{~m}$ area with the container at the center. Vegetation density was categorized as sparse, medium, or dense, and vegetation height as ground-hugging, medium, or tall. Coarse woody debris was only present for covered containers, and all CWD areas were selected from naturally occurring debris areas (Orrock and Danielson 2009). Exact volumetric quantification of coarse woody debris was not necessary, as this study evaluated the difference in presence/absence of CWD, and not variation within CWD preference based on relative quantities (Barko et al. 2003). On the habitat assessment plots, I recorded the presence of all honeysuckle shrubs with dbh (diameter at breast height) $>2.5 \mathrm{~cm}$ and trees with $\mathrm{dbh}>$ $10 \mathrm{~cm}$. The presence of large logs (diameter $>35 \mathrm{~cm}$ ) was separated from CWD and recorded. Measurements of microhabitat allow comparison within habitat types to confirm the degree of continuity across stations.

Weather data were gathered for each sampling day, and included the following variables:

mean temperature, $\%$ humidity, cloud cover, and $\%$ moon disk illuminated. Weather data were gathered from online archives available through The Weather Channel (2015) for the zip code 40207 which includes Twin Parks. Percent moon illuminated and moon phase data were collected from tables on the website Lunar Calendar (lunaf.com/english/moon-phases).

\section{Measuring Giving-up Density}

Each of the 36 containers consisted of a transparent 6-quart plastic box $(35.5 \mathrm{~cm} \mathrm{~L} \mathrm{x} 20$ $\mathrm{cm} \mathrm{W} \times 13 \mathrm{~cm} \mathrm{H}$ ) with a translucent, locking plastic lid. Two $2.5 \mathrm{~cm}$ holes were cut into 
each side of the longest container axis, approximately $2 \mathrm{~cm}$ from one end and $4 \mathrm{~cm}$ up from the bottom. This size of hole excluded eastern chipmunks (Tamias striatus), while allowing access by white-footed mice. Twenty ounces of sand were placed in each container and evenly distributed on the bottom to a depth of about $3.5 \mathrm{~cm}$. I used sunflower seeds as bait for the GUD containers. Three days prior to placement in the field, $6 \mathrm{~g}$ of sunflower seeds were weighed for each container. In the field, the sunflower seeds were mixed into the sand in each container by hand. The seeds were concentrated at the end of the container away from the holes so that mice would fully traverse the container to reach the food. Consequently, the presence of tracks in the sand allowed for verification of foraging and identification of foragers.

Containers were set out in mid-afternoon and sampled between 13:45 hrs and 15:00 hrs each subsequent day for up to five days. All GUD sessions were run when the moon was $35-85 \%$ full. Each container was placed in the designated treatment location with the lid locked and left for 24 hours. After 24 hours, sunflower seeds were removed from the sand using a hand-sieve with $1 \mathrm{~mm}$ mesh. A new $6.00 \mathrm{~g}$ sample of sunflower seeds was then added to the sand for the next day's trial. All material remaining in the sieve was placed in a labeled plastic bag for further processing. All sand was sifted immediately before and after each trial to ensure sand grains would not be caught in the sieve. Similarly, all sunflower seeds were sifted immediately prior to weighing so no piece would be small enough to fall through the sieve. 
Once a trial was complete, all sunflower seeds sifted from the containers were carefully hand-sorted to remove any clumped sand or fecal material, and then carefully weighed to obtain the remaining mass. Although there was no rainfall during the sampling periods, high humidity caused cohesion within the majority of the sand on some days. If the sand had accumulated enough moisture to clump prior to the sifting of the sunflower seeds, each of the 36 seed samples collected for that day were put into test tubes and placed in a low-temperature $\left(38^{\circ} \mathrm{C}\right)$ drying oven for six hours to reduce excess moisture. Six hours of drying generally was sufficient to remove excess moisture absorbed by the seeds in the field, which would otherwise have influenced GUD. To ensure that the moisture content of the dried seeds was consistent with moisture content prior to placement, six control seed samples were dried along with each set of 36 container seed samples. The control seeds were weighed out to exactly $6.00 \mathrm{~g}$ from the standard seed stock used to fill premeasured bags, and reweighed after drying to assess water content lost. The control seed samples never lost more than $0.01 \mathrm{~g}$ during the six hour drying period. This research was approved by the University of Louisville Animal Care and Use Committee (proposal \#13094) and followed the guidelines of the American Society of Mammalogists (Sikes et al. 2011).

\section{Statistical Analysis}

Habitat variables were compared among treatments using analysis of variance. Cover treatments were analyzed separately because both a cover and no-cover container were present at each station and thus had overlapping habitat data. No coarse woody debris was present for any no-cover container, but all cover containers had a CWD habitat 
variable. Analyses were conducted with R (R Core Team 2015) or SPSS (IBM SPSS version 21).

GUD was evaluated using a linear mixed-effects model with repeated measures. The fixed-effects explanatory variables were habitat and cover, with day as the repeated measure. Moon illumination, mean temperature, humidity, and cloud cover were included as covariates, and station was included as a random effect. This model used maximum likelihood ratio tests to calculate the significance of each effect and interactions. The Kenward-Rogers method was used to calculate denominator degrees of freedom. The analysis started with a full model, including five-way interactions, and interactions were removed in subsequent iterations if they were not significant at $p<0.15$ (Mattos and Orrock 2010). The linear mixed effects model used R packages 'ImerTest' (Kuznetsova et al. 2015), 'lme4' (Bates et al. 2015), and 'pbkrtest' (Halekoh and Højsgaard 2014).

\section{RESULTS}

I collected 576 samples over 16 days at this site. However, on the nights of July 16th and November 1st containers experienced heavy disturbance from raccoons (Procyon lotor), and accordingly GUDs for all stations on those nights were not included in the analysis, leaving a total of 504 samples. All containers were visited by small mammals each night, as indicated by tracks and disturbance of the seeds. None of the habitat variables differed among stations within each cover treatment (Table 6a) and thus they were not included in further analyses. However, all three weather variables, relative humidity $(p=0.001)$, 
mean temperature $(p<0.0001)$, and cloud cover $(p=0.0001)$, as well as \% moon illuminated $(p<0.0001)$, varied significantly over the 14 days sampled at this site (Figure 1, Table 6b). 


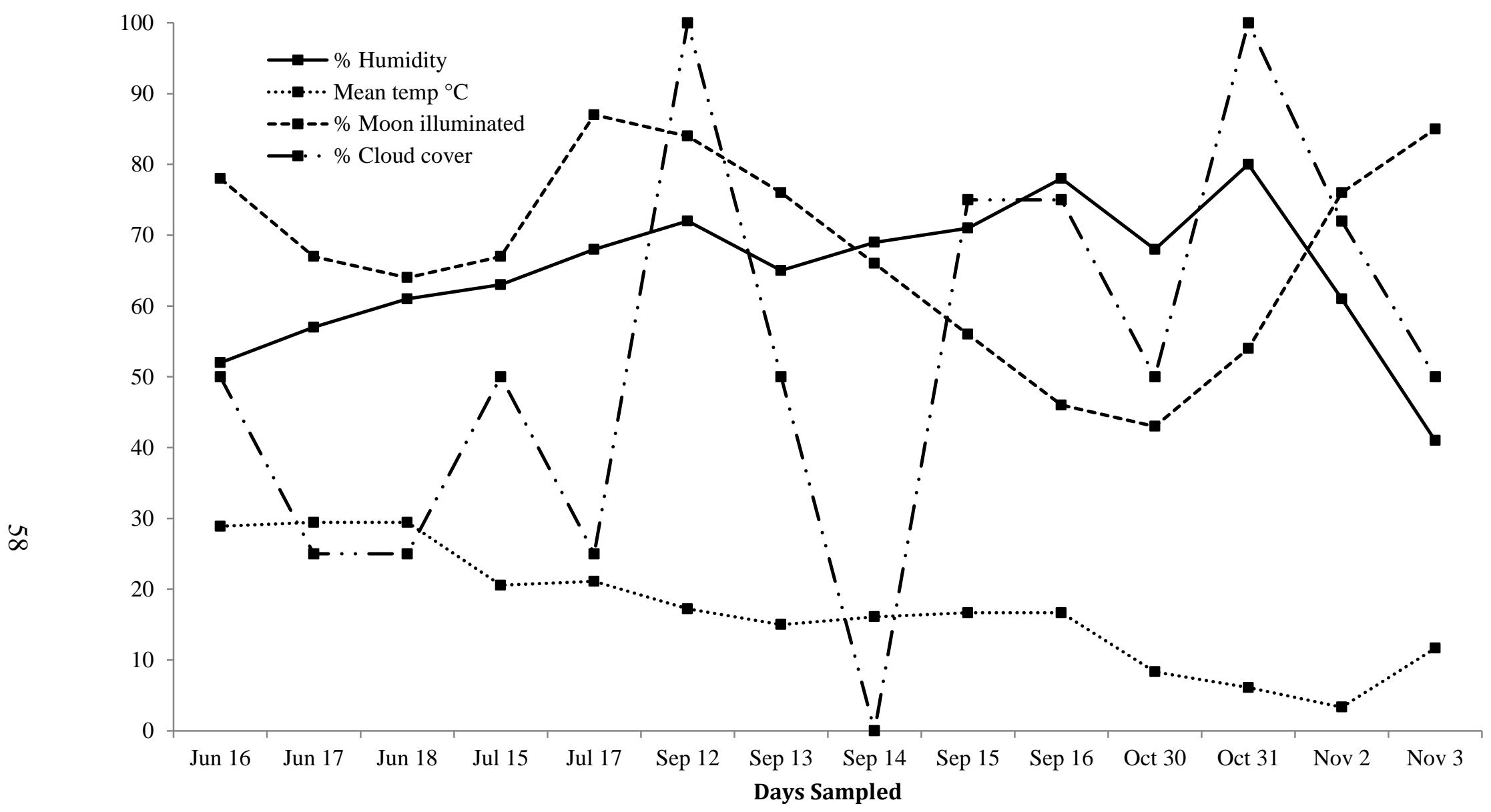

FIGURE 1. Variation in percent humidity, mean temperature, percent moon visible, and percent cloud cover over the sampled days. 
Table 6. ANOVAs for a) microhabitat variables; treatments cover and no cover split, $\mathrm{df}=$ 17 and b) temporal weather variables. Df $=1$

A) Microhabitat variables

\begin{tabular}{lrll}
\hline & \multicolumn{1}{c}{ SS } & F & P \\
\hline \multicolumn{1}{c}{ No Cover } & & & \\
Veg height & 22.278 & 0.153 & 0.860 \\
Veg density & 22.278 & 0.785 & 0.474 \\
Honeysuckle & 1.278 & 0.870 & 0.439 \\
Tree & 3.111 & 0.278 & 0.761 \\
Log & 2.500 & 1.154 & 0.342 \\
$\quad$ & & & \\
$\quad$ Cover & & & \\
CWD & 8.500 & 1.395 & 0.278 \\
Veg height & 22.278 & 0.153 & 0.860 \\
Veg density & 14.500 & 0.176 & 0.840 \\
Honeysuckle & 4.444 & 1.591 & 0.236 \\
Tree & 4.000 & 2.500 & 0.116 \\
Log & 4.000 & 0.682 & 0.521 \\
\hline
\end{tabular}

B) Temporal

\begin{tabular}{lrrc}
\hline & SS & \multicolumn{1}{c}{$\mathrm{F}$} & $\mathrm{P}$ \\
\hline \% Moon visible & 465.5 & 30.246 & $<<0.0001$ \\
\% Humidity & 165.6 & 10.356 & 0.001 \\
Mean temp & $6,925.1$ & $2,748.300$ & $<<0.0001$ \\
\% Cloud cover & $1,481.5$ & 110.860 & $<<0.0001$ \\
\hline
\end{tabular}

\section{Assessment of GUD}

White-footed mice had the lowest GUDs under the honeysuckle canopy and CWD cover, and they had the highest GUDs at containers with no cover in the edge and open habitats (Figure 2). There was significant difference in GUDs across the sampled days $\left(F_{9,488}=\right.$ 3.92, $p=0.0001$; Table 7), with the highest GUD's in June and the greatest variation between treatments in October (Figure 2). The interactions between day and habitat, day and cover, or day and the other covariates were not significant. The interactions humidity 
$\mathrm{x}$ habitat $\left(F_{1,486}=5.10, p=0.024\right)$ and humidity $\mathrm{x} \operatorname{cover}\left(F_{1,473}=5.60, p=0.018\right)$ were both significant, as was the three-way interaction among mean temperature $\mathrm{x}$ habitat $\mathrm{x}$ $\operatorname{cover}\left(F_{1,459}=6.05, P=0.014\right)$. The three-way interaction among percent moon illuminated $\mathrm{x}$ habitat $\mathrm{x}$ cover was marginally significant $\left(F_{1,458}=3.05, P=0.08\right)$.

Table 7. Mixed models effects table examining factors effecting GUD in Peromyscus leucopus. Fixed effects are habitat type, cover presence, day, percent moonlight, percent relative humidity, mean temperature, and cloud cover. Habitat and cover were considered main effects and the rest treated as covariates. Station was a random variable. Only interactions with $p<0.25$ are present. $* * * *<0.001, * * *<0.005, * *<0.01, *<0.05$, $<0.1, \mathrm{df}=503$

\begin{tabular}{|c|c|c|c|}
\hline Effect & Df & $F$ & $P$ \\
\hline \multicolumn{4}{|l|}{ Temporal } \\
\hline Habitat & 1,502 & 18.86 & $<0.0001 * * * *$ \\
\hline Cover & 1,501 & 7.10 & $0.008 * *$ \\
\hline Humidity & 1,500 & 10.87 & $0.001 * * *$ \\
\hline Temp & 1,499 & 1.35 & 0.25 \\
\hline Moonlight & 1,498 & 0.98 & 0.323 \\
\hline Cloud & 1,497 & 1.88 & 0.172 \\
\hline Day & 9,488 & 3.92 & $0.0001 * * * *$ \\
\hline Habitat x Humidity & 1,486 & 5.10 & 0.024 \\
\hline Habitat x Temp & 1,485 & 7.39 & $0.007 \quad * *$ \\
\hline Cover x Humidity & 1,473 & 5.60 & 0.018 \\
\hline $\begin{array}{l}\text { Habitat } \mathrm{x} \text { Cover } \mathrm{x} \\
\text { Temp }\end{array}$ & 1,459 & 6.05 & 0.014 \\
\hline $\begin{array}{l}\text { Habitat x Cover } \mathrm{x} \\
\text { Moonlight }\end{array}$ & 1,458 & 3.05 & 0.08 \\
\hline
\end{tabular}




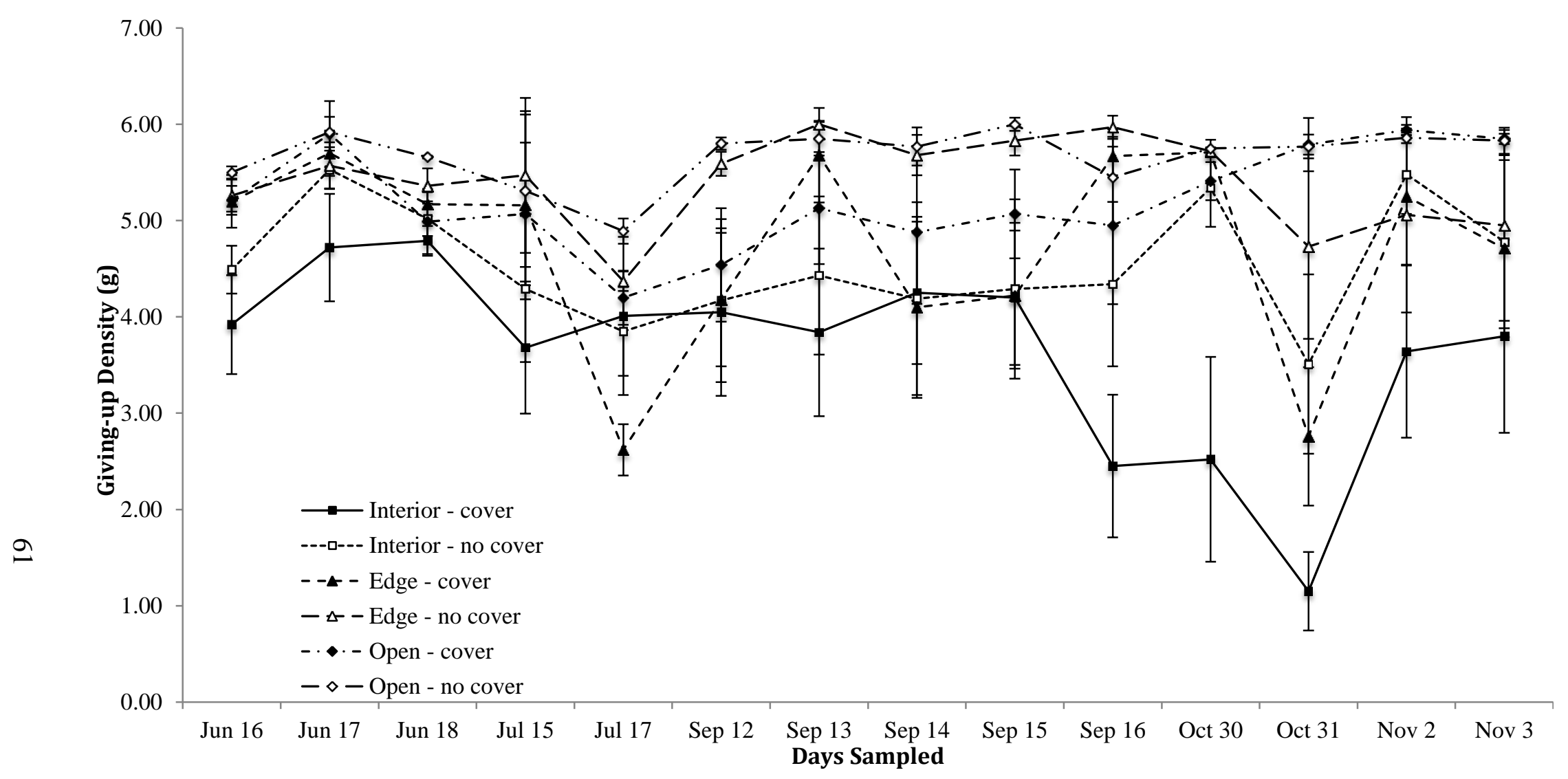

FIGURE 2. Comparison of giving-up densities between habitat types and cover. Giving-up density represents grams of sunflower seed remaining. Meanst/- $1 \mathrm{SE}$ are shown 


\section{DISCUSSION}

Following my first hypothesis, results of this study indicate that white-footed mice foraged to lower densities in the presence of Amur honeysuckle and CWD. This behavior is consistent with patterns of habitat use in both non-urban (Drickamer 1990; Greenberg 2002) and urban (Jones and Lindquist 2012; Chupp et al. 2013) sites. Mice at this site selected for those areas providing greater overhead protection from predators, in the form of the shrub canopy and CWD, supporting previous studies of small mammals in more natural habitats (Adler and Wilson 1987; Brown et al. 1988; Greenberg 2002; Bakker 2006; Hodson et al. 2010).

However, the response of white-footed mice to abiotic factors showed their foraging behavior has shifted in subtle and complex ways. All four environmental factors varied significantly and influenced the foraging behavior of white-footed mice. The lack of significance at the microhabitat level, accompanied by the significance of environmental factors, shows that macrohabitat factors are primarily influencing patterns in foraging effort (Bellows et al. 2001). Finer-scale microhabitat factors such as CWD, an important component of predator avoidance behavior (Wolf and Batzli 2004), shaped distributions within the preferred macrohabitat types.

This study showed that the interaction of humidity $\mathrm{x}$ cover and humidity $\mathrm{x}$ habitat significantly affected white-footed mouse foraging activity. While the interaction between these factors shows that no one factor by itself regulated GUD, the factors of CWD cover and habitat type present relatively obvious discussion. The nature of these 
two factors also presents relatively clear interpretation of their influence. It is the third variable included, humidity, which warrants deeper investigation to determine how it can interact with habitat and cover to influence GUD.

Increased humidity can increase metabolic costs (Kotler et al. 1993), potentially reducing foraging effort in small mammals. Higher metabolic costs would likely cause whitefooted mice to select for habitat where they feel more secure and can obtain a higher yield from each patch. This increased cost would lead to mice increasing selection for CWD and shrub cover. Humidity also affects olfaction, as higher humidity increases volatility and makes detection of some foods easier, which may to some degree counteract the higher metabolic costs (Kotler et al. 1993; Wall 2003). As costs associated with foraging increase, we would expect mice to increase risk-aversive behaviors, placing more emphasis on foraging in those areas that provide the greatest protection from predation. This effect of humidity helps explain the interaction with cover and habitat. When humidity increased, GUD's were higher in the open, with the least variation under the honeysuckle canopy and with CWD cover.

In this study temperature interacted with habitat and CWD cover to influence giving-up densities across treatments. As with humidity, the ability of cover and habitat factors to influence GUD is relatively straightforward, as we would expect for CWD and shrub canopy to be selected for. It is the inclusion of temperature as a coregulatory factor that must be reflected upon. The ability of temperature to increase metabolic costs (Fanson 2010) was likely mediated by honeysuckle, through maintenance of lower temperatures 
under the canopy. This would reduce thermoregulatory costs, making habitat with greater cover more desirable in higher temperatures. This cooling effect also potentially affected CWD cover, as CWD provides some element of shade in habitats with less canopy cover. GUD varied to a greater degree between cover and no-cover treatments in the edge and open habitats relative to the interior of the honeysuckle patch as temperatures increased. While white-footed mice are primarily active between dusk and dawn when temperatures are lower, the urban heat island effect reduces heat dissipation and increases nighttime temperatures (Oke 1982; Deichsel 2006).

My second hypothesis was not supported by the results, in that moonlight did not affect GUD even though it varied significantly across sampled days. Moonlight generally plays an important role in anti-predator behavior and is an indirect indicator of predation risk known to affect $P$. leucopus both in non-urban habitats (Zollner and Lima 1999; Mattos and Orrock 2010; Prugh and Golden 2014) and in areas with L. maackii (Mattos and Orrock 2010). The interaction between moonlight, habitat, and cover was marginally significant, and likely reflects the variation in illumination reaching the ground through the varying levels of honeysuckle canopy and CWD cover across the six treatments. This filtering effect likely explains variation in degree of response in terms of foraging effort and GUD, with the highest densities in the open, and the greatest variation across treatments occurring when more of the moon was visible.

Moonlight's lack of significance is surprising, as moonlight is well-known to affect foraging behavior (Prugh and Golden 2014). While this study showed moonlight to only 
have a marginal effect as an interaction, moonlight and honeysuckle canopy have interacted to significantly alter GUD and anti-predator behavior in a non-urban environment (Mattos and Orrock 2010). Understanding what factors may have diminished the role of moonlight can reveal important clues about foraging behavior in the urban environment. While we cannot determine which, if any, factor played a role in this study due to the nature of the interaction and lack of data, it creates an avenue for future research.

The first factor that could have reduced the response to moonlight, and created a more even response across habitat and cover types, is a reduced predator presence. However, northern raccoons (Eagan et al. 2011) and domestic cats (Baker et al. 2005; BricknerBraun et al. 2007; Krauze Gryz et al. 2012) were observed during this study, and both species can reach high densities and thus are potentially important predators of small mammals in urban areas (Hoffmann and Gottschang 1977; Smith and Engeman 2002; Finkler et al. 2011). The second factor is ecological light pollution, a greater degree of direct and background illumination in urban zones at night due to artificial lighting (Longcore and Rich 2004). The increase in illumination of urban areas affects bat foraging and flight behavior (Stone et al. 2009; Polak et al. 2011; Lewanzik and Voigt 2014), alters foraging behavior in crepuscular species, and can increase activity times for diurnal species (Longcore and Rich 2004; Kempenaers et al. 2010; Stracey et al. 2014). The potential for any light pollution to be diminished under the honeysuckle canopy is not as great as with moonlight, due to a greatly decreased angle of incidence and the more diffuse nature of light pollution. Finally, the relatively small variation in moonlight 
sampled here may not have presented enough difference in illumination to elicit a significant response from the white-footed mouse population. While the variation in percent moon illuminated was highly significant over the nights sampled, the moon phase sample is relatively homogenous and may not have affected mice as greatly as a full lunar cycle would.

Data on cloud cover also supported the idea that natural light has a reduced role in determining small mammal foraging patterns in urban areas. As is the case with moonlight, cloud cover is known to influence small mammal foraging behavior in natural areas, with small mammals in general (Kotler et al. 1993) and Peromyscus leucopus in particular (Orrock et al. 2004) having lower GUDs when cloud cover is high. However, although cloud cover varied significantly over the course of this study, it did not have a significant independent effect on GUD, cloud cover and moonlight did not have a significant interaction effect, nor did cloud cover interact with any other variable. This indicates a possible reduction in its importance for anti-predator risk assessment. In natural areas, the degree of cloud cover affects the amount of moonlight that reaches the ground, mitigating the influence of moonlight. Urban areas in general are brighter than neighboring non-urban areas, and in urban areas, cloud cover that would block moonlight can increase illumination by reflecting artificial light back to the ground (Kyba et al. 2011). 


\section{CONCLUSION}

This study demonstrated that Peromyscus leucopus is a strong habitat generalist, able to persist in this urban park through modification of behavior. White-footed mice appeared to readily adjust habitat preferences and foraging activity around the best available options presented. The dominance of Amur honeysuckle may be partly responsible for the low small mammal species diversity, but $P$. leucopus was able to use this shrub effectively.

Peromyscus leucopus displayed a high degree of variation in habitat selection at the macrohabitat scale, while primarily selecting for habitat under the honeysuckle midcanopy layer. This raised questions as to what kinds of habitat were under the canopy, and how these habitats were being used. This study determined white-footed mice used the CWD under the canopy as their primary habitat choice, selecting for areas with higher abundances of CWD. White-footed mice also used the honeysuckle canopy as a likely movement corridor and potential foraging area when in leaf.

\section{Practical Implications}

While this study only used one research site, the type of park chosen is not uncommon. Forested parks are prevalent throughout the eastern United States of America, and Amur 
honeysuckle is invasive in 23 states (Hutchinson and Vankat 1998). Perhaps the most unique aspect of Twin Parks in relation to others is the floodplain, but most of the critical information came from within the honeysuckle patch. The findings of this study likely apply to other urban forest parks or even non-urban forest habitats experiencing a high level of Amur honeysuckle invasion.

White-footed mice do appear to use Amur honeysuckle, as seen in non-urban settings (Mattos and Orrock 2010; Dutra et al. 2011; Shields et al. 2014). The dense shrub canopy provides cover from predators and the high canopy connectivity creates movement and foraging options. The benefits provided by the honeysuckle appear to outweigh the negative impacts, namely the suppression of vegetative diversity under the honeysuckle canopy. A contributing factor in this equation is the prevalence of CWD, the favored microhabitat option, under the honeysuckle canopy. This preferences for CWD agrees with other studies of white-footed mice in highly disturbed non-urban habitats (Greenberg 2002; Kellner and Swihart 2014), but disagrees with a study of P. leucopus in another urban forest (Jones and Lindquist 2012).

\section{Future Efforts}

The results of these experiments suggest multiple avenues for future research efforts. The primary task should likely be to expand this study into multiple parks and habitat types to confirm the applicability of the results. Microhabitat selection by a strong generalist species will conform to the available resources, providing a clear picture of the key 
elements in assessed habitats. Further study in new areas will also provide more insight into the reduction of the small mammal community. Understanding the role of Amur honeysuckle in regulating both the plant community and the small mammal community will help us better understand the effects of large-scale removals, and the chances for recolonization. Human presence had little impact on white-footed mice in this area, but it was also little-used. Quantifying response to human activity in similar areas that contain more widespread and managed trails can also determine at what level human presence becomes a factor.

The major urban factor that possessed the greatest posibility of an ecosystem-level impact was ecological light pollution. While not fully supported in this study, the suggestion that light pollution can mitigate the impact of moonlight and cloud cover on nocturnal foraging has strong repercussions for urban foraging behavior. Further studies should examine small mammal responses to urban luminance in greater detail. Such studies should directly measure luminance and compare foraging behavior at urban and rural or natural areas. Future research should also test for the effects of moonlight across all moon phases, and investigate the effects of cloud cover, including clouds at different altitudes in order to examine differences in light reflection with cloud altitude. Understanding the relative impact of the microclimate effect in relation to variation in illumination at ground level is another area for future study and an important next step for understanding the behavior of $P$. leucopus and other small mammals in urban habitats. 


\section{REFERENCES}

Abbott H G, Quink T F 1970. Ecology of eastern white pine seed caches made by small forest mammals. Ecology 51: 271-278.

Adler G H, Wilson M L (1987). Demography of a habitat generalist, the white-footed mouse, in a heterogeneous environment. Ecology 68: 1785-1796.

Anderson C S, Cady A B, Meikle D B (2003). Effects of vegetation structurea nd edge habitat on the density and distribution of white-footed mice (Peromyscus leucopus) in small and large forest patches. Canadian Journal of Zoology 81(5): 897-904.

Anderson D C, Folk M L (1993). Blarina brevicauda and Peromyscus leucopus reduce overwinter survivorship of acorn weevils in an Indiana hardwood forest. Journal of Mammalogy 74: 656-664.

Angold P G, Sadler J P, Hill M O, Pullin A, Rushton S, Austin K, Small E, Wood B, Wadsworth R, Sanderson R, Thompson K (2006). Biodiversity in urban habitat patches. Science of the Total Environment 360(1-3): 196-204.

Baker P J, Ansell R J, Dodds P A A, Webber C E, Harris S (2003). Factors affecting the distribution of small mammals in an urban area. Mammal Review 33(1): 95-100.

Baker P J, Bentley A J, Ansell R J, Harris S (2005). Impact of predation by domestic cats Felis catus in an urban area. Mammal Review 35: 302-312.

Bakker V J (2006). Microhabitat features influence the movements of red squirrels (Tamiasciurus hudsonicus) on unfamiliar ground. Journal of Mammalogy 87: 124-130.

Barko V A, Felhnamer G A, Nicholson M C, Davie D K (2003). Urban habitat: a determinant of white-footed mouse (Peromyscus leucopus) abundance in southern illinois. The Southeastern Naturalist 2(3): 369-376. 
Barnum S A, Manville C J, Tester J R, Carmen W J (1992). Path selection by Peromyscus leucopus in the presence and absence of vegetative cover. Journal of Mammalogy 73(4): 797-801.

Bartuszevige A M, Gorchov D L, Raab L (2006). The relative importance of landscape and community features in the invasion of an exotic shrub in a fragmented landscape. Ecography 29(2): 213-222.

Bateman P W, Fleming P A (2012). Big city life: carnivores in urban environments. Journal of Zoology 287: 1-23.

Bates D, Maechler M, Bolker B, Walker S (2015). lme4: Linear mixed-effects models using Eigen and S4. R package version 1.1-8, <URL: http://CRAN.Rproject.org/package $=$ lme $4>$.

Batzli G (1977). Population dynamics of the white-footed mouse in floodplain and upland Forests. American Midland Naturalist 97: 18-32.

Bedoya-Perez M A, Carthey A J R, Mella V S A, McArthur C, Banks P B (2013). A practical guide to avoid giving up on giving-up densities. Behavioral Ecology and Sociobiology 67: 1541-1553.

Bellows A S, Pagels J F, Mitchell J C (2001). Macrohabitat and microhabitat affinities of small mammals in a fragmented landscape on the upper Coastal Plain of Virginia. American Midland Naturalist 146(2): 345-360.

Borgmann K L, Rodewald A D (2004). Nest predation in an urbanizing landscape: the role of exotic shrubs. Ecological Applications 14(6): 1757-1765.

Bowers M A (1990). Exploitation of seed aggregates by merriam kangaroo rat harvesting rates and predatory risk. Ecology 71: 2334-2344.

Bowers M A, Dooley J L (1993). Predation hazard and seed removal by small mammals - microhabitat versus patch scale effects. Oceologia 94(2): 247-254.

Boyce R L (2010). Invasive shrubs in Kentucky. Northeast Naturalist 17: 1-36.

Brannon M P (2005). Distribution and microhabitat of the woodland jumping mouse, Napaeozapus insignis, and the white-footed mouse, Peromyscus leucopus, in the Southern Appalachians. Southeastern Naturalist 4: 479-486.

Brickner-Braun I, Geffen E, Yom-Tov Y (2007). The domestic cat as a predator of Israeli wildlife. Israel Journal of Ecology and Evolution 53: 129-142. 
Brillhart D B, Kaufman D W (1991). Influence of illumination and surface-structure on space use by prairie deer mice (Peromyscus-maniculatus-bairdii). Journal of Mammalogy 72: 764-768.

Brown J S (1988). Patch use as an indicator of habitat preference, predation risk, and competition. Behavioral Ecology and Sociobiology 22: 37-47.

Brown J S (1992). Patch use under predation risk .1. models and predictions. Annales Zoologici Fennici 29: 301-309.

Brown J S, Kotler B P (2004). Hazardous duty pay and the foraging cost of predation. Ecology Letters 7: 999-1014.

Brown J S, Kotler B P, Smith R J, Wirtz W O (1988). The Effects of owl predation on the foraging behavior of heteromyid rodents. Oecologia 76: 408-415.

Cavia R, Cueto G R, Suarez O V (2009). Changes in rodent communities according to the landscape structure in an urban ecosystem. Landscape and Urban Planning 90: 11-19.

Charnov E L (1976). Optimal foraging, marginal value theorem. Theoretical Population Biology 9: 129-136.

Chupp A D, Roder A M, Battaglia L L, Pagels J F (2013). A case study of urban and peri-urban mammal communities: implications for the management of national park service areas. Northeastern Naturalist 20(4): 631-654.

Chytry M, Jarosik V, Pysek P, Hajek O, Knollova I, Tichy L, Danihelka J (2008). Separating habitat invasibility by alien plants from the actual level of invasion. Ecology 89: 1541-1553.

Collier M H, Vankat J L, Hughes M R (2002). Diminished plant richness and abundance below Lonicera maackii, an invasive shrub. American Midland Naturalist 147: 60-71.

Cornelis J, Hermy M (2004). Biodiversity relationships in urban and suburban parks in Flanders. Landscape and Urban Planning 69(4): 385-401.

Creel S, Christianson D (2008). Relationships between direct predation and risk effects. Trends in Ecology and Evolution 23: 194-201.

Crooks K R (2002). Relative sensitivities of mammalian carnivores to habitat fragmentation. Conservation Biology 16: 488-502.

Deering R H, Vankat J L (1999). Forest colonization and developmental growth of the invasive shrub Lonicera maackii. American Midland Naturalist 141: 43-50. 
Deichsel R (2006). Species change in an urban setting-ground and rove beetles (Coleoptera: Carabidae and Staphylinidae) in Berlin. Urban Ecosystems 9(3): 161-178.

Drickamer L C (1990). Microhabitat preferences for 2 species of deermice Peromyscus in a northeastern United States deciduous harwood forest. Acta Theriologica 34(34): 241-252.

Dutra H P, Barnett K, Reinhardt J R, Marquis R J, Orrock J L (2011). Invasive plant species alters consumer behavior by providing refuge from predation. Oecologia 166: 649-657.

Eagan T S, Beasley J C, Olson Z H, Rhodes O E (2011). Impacts of generalist mesopredators on the demography of small-mammal populations in fragmented landscapes. Canadian Journal of Zoology 89(8): 724-731.

Edalgo J A, Anderson J T (2007). Effects of prebaiting on small mammal trapping success in a morrow's honeysuckle-dominated area. Journal of Wildlife Management 71: 246-250.

Edalgo J A, McChesney H M, Love J P, Anderson J T (2009). Microhabitat use by whitefooted muce Peromyscus leucopus in forested and old--field habitats occupied by Morrow's honeysuckle Lonicera morrowii. Current Zoology 55: 111-122.

Fanson B G (2010). Effect of direct and indirect cues of predation risk on the foraging behavior of the white-footed mouse (Peromyscus leucopus). Northeastern Naturalist 17: 19-28.

Fauteux D, Imbeau L, Drapeau P, Mazerolle M J (2012). Small mammal responses to coarse woody debris distribution at different spatial scales in managed and unmanaged boreal forests. Forest Ecology and Management 266: 194-205.

Fernandex-Juricic E (2001). Avian spatial segregation at edges and interiors of urban parks in Madrid, Spain. Biodiversity and Conservation 10(8): 1303-1316.

Finkler H, Hatna E, Terkel J (2011). The influence of neighbourhood socio-demographic factors on densities of free-roaming cat populations in an urban ecosystem in Israel. Wildlife Research 38(3): 235-243.

Francis R A, Chadwick M A (2012). What makes a species synurbic? Applied Geography 32: 514-521.

Godefroid S (2001). Temporal analysis of the Brussels flora as indicator for changing environmental quality. Landscape and Urban Planning 52: 203-224. 
Gorchov D L, Trisel D E (2003). Competitive effects of the invasive shrub, Lonicera maackii (Rupr.) Herder (Caprifoliaceae), on the growth and survival of native tree sseedlings. Plant Ecology 166: 13-24.

Gordon D R (1998). Effects of invasive, non-indigenous plant species on ecosystem processes: Lessons from Florida. Ecological Applications 8: 975-989.

Greenberg C H (2002). Response of white-footed mice (Peromyscus leucopus) to coarse woody debris and microsite use in southern Appalachian treefall gaps. Forest Ecology and Management 164: 57-66.

Halekoh U, Højsgaard S (2014). A Kenward-Roger approximation and parametric bootstrap methods for tests in linear mixed models - The R Package pbkrtest. Journal of Statistics Software 59(9): 1-30.

Harmon L J, Bauman K, McCloud M, Parks J, Howell S, Losos JB (2005). What freeranging animals do at the zoo: A study of the behavior and habitat use of opossums (Didelphis virginiana) on the grounds of the St. Louis Zoo. Zoo Biology 24: 197-213.

Hartman K M, McCarthy B C (2008). Changes in forest structure and species composition following invasion by a non-indigenous shrub, Amur honeysuckle (Lonicera maackii). The Journal of the Torry Botanical Society 135: 245-259.

Hinkelman T M, Orrock J L, Loeb S C (2012). Effect of downed woody debris on small mammal anti-predator behavior. Ethology 118: 17-23.

Hobbs E R (1988). Species richness of urban forest patches and implications for urban landscape diversity. Landscape Ecology 1: 141-152.

Hodson J, Fortin D, Belanger L (2010). Fine-scale disturbances shape space-use patterns of a boreal forest herbivore. Journal of Mammalogy 91: 607-619.

Hoffmann C O, Gottschang J L (1977). Numbers, distribution, and movements of a raccoon population in a suburban residential community. Journal of Mammalogy 58: 623-636.

Horncastle V J, Hellgren E C, Mayer P M, Engle D M, Leslie D M (2004). Differential consumption of eastern red cedar (Juniperus virginiana) by avian and mammalian guilds: Implications for tree invasion. American Midland Naturalist 152: 255-267.

Horvath A, March I J, Wolf J H D (2001). Rodent diversity and land use in Montebello, Chiapas, Mexico. Studies on Neotropical Fauna and Environment 36: 169-176. 
Huang G L, Zhou W Q, Cadenasso M L (2011). Is everyone hot in the city? Spatial pattern of land surface temperatures, land cover and neighborhood socioeconomic characteristics in Baltimore, MD. Journal of Environmental Management 92(7): 1753-1759.

Hutchinson T F, Vankat J L (1998). Landscape structure and spread of the exotic shrub Lonicera maackii (Amur honeysuckle) in southwestern Ohio forests. American Midland Naturalist 139: 383-390.

Ingold J L, Craycraft M J (1983). Avian frugivory on honeysuckle (Lonicera) in southwestern Ohio in fall. Ohio Journal of Science 83: 256-258.

Jackson D A (1993). Stopping rules in principal components-analysis - a comparison of heuristic and statistical approaches. Ecology 74: 2204-2214.

Jenerette G D, Wu J G (2001). Analysis and simulation of land-use change in the central Arizona-Phoenix region, USA. Landscape Ecology 16: 611-626.

Johnson, M D, DeLeon Y L (2015). Effect of an invasive plant and moonlight on rodent foraging behavior in a coastal dune ecosystem. Plos One 10(2): e0117903.

Jones C G, Lindquist E S (2012). Utilization of woody debris by Peromyscus leucopus in a fragmented urban forest. The Southeastern Naturalist 11(4): 689-698.

Kellner K F, Swihart R K (2014). Changes in small mammal microhabitat use following silvicultural disturbance. American Midland Naturalist 172: 348-358.

Kempenaers B, Borgstrom P, Loes P, Schlicht E, Valcu M (2010). Artificial night lighting affects dawn song, extra-pair siring success, and lay date in songbirds. Current Biology 20: 1735-1739.

KnowWare International @2015. QI Macros: Sample Size Calculator. V. 2010.01. Last accessed 11/04/2012.

Kostel-Hughes F, Young T P, Carreiro M M (1998). Forest leaf litter quantity and seedling occurrence along an urban-rural gradient. Urban Ecosystems 2(4): 263278.

Kotler B P, Ayal Y, Subach A (1994). Effects of predatory risk and resource renewal on the timing of foraging activity in a gerbil community. Oecologia 100: 391-396.

Kotler B P, Brown J S, Mitchell W A (1993). Environmental-factors affecting patch use in 2 species of gerbilline rodents. Journal of Mammalogy 74: 614-620. 
Krauze-Gryz D, Gryz J, Goszczynski J (2012). Predation by domestic cats in rural areas of central Poland: an assessment based on two methods. Journal of Zoology 288: 260-266.

Kuznetsova A, Brockhoff P B, Christensen R H B (2015). lmerTest: Tests in Linear Mixed Effects Models. R package version 2.0-29.

Kyba C C M, Ruhtz T, Fischer J, Holker F (2011). Cloud coverage acts as an amplifier for ecological light pollution in urban ecosystems. Plos One 6(3): \# e17307.

Lambdon, P W, Pysek P, Basnou C, Hejda M, Arianoutsou M, Essl F, Jarosik V, Pergl J, Winter M, Anastasiu P, Andriopoulos P, Bazos I, Brundu G, Celesti-Grapow L, Chassot P, Delipetrou P, Josefsson M, Kark S, Klotz S, Kokkoris Y, Kuhn I, Marchante H, Perglova I, Pino J, Vila M, Zikos A, Roy D, Hulme P E (2008). Alien flora of Europe: species diversity, temporal trends, geographical patterns and research needs. Preslia 80: 101-149.

Lemaître J, Fortin D, Morris D W, Darveau M (2010). Deer mice mediate red-backed vole behaviour and abundance along a gradient of habitat alteration. Evolutionary Ecology Research 12: 203-216.

Lewanzik D, Voigt C C (2014). Artificial light puts ecosystem services of frugivorous bats at risk. Journal of Applied Ecology 51: 388-394.

Lima S L, Dill L M (1990). Behavioral decisions made under the risk of predation - a review and prospectus. Canadian Journal of Zoology 68: 619-640.

Loeb R E (2006). A comparative flora of large urban parks: intraurban and interurban similarity in the megalopolis of the northeastern United States. The Journal of the Torry Botanical Society 133: 601-625.

Longcore T, Rich C (2004). Ecological light pollution. Frontiers in Ecology and the Environment 2: 191-198.

Luken J O, Thieret J W (1996). Amur honeysuckle, its fall from grace. Bioscience 46: 1824.

Lunar Calendar. (2015). Lunar calendar for 2014 by week and month. www.lunaf.com/ lunar-calendar/2014. Last Accessed 28 January 2015.

Mahan C G, O'Connell T J (2005). Small mammal use of suburban and urban parks in central Pennsylvania. Northeastern Naturalist 12: 307-314.

Manson R H, Stiles E W (1998). Links between microhabitat preferences and seed predation by small mammals in old fields. Oikos 82: 37-50. 
Mattos K J, Orrock J L (2010). Behavioral consequences of plant invasion: an invasive plant alters rodent antipredator behavior. Behavioral Ecology 21: 556-561.

McEwan R W, Arthur-Paratley L G, Rieske L K, Arthur M A (2010). A multi-assay comparison of seed germination inhibition by Lonicera maackii and co-occurring native shrubs. Flora 205: 475-483.

McKinney M L (2002). Urbanization, biodiversity, and conservation. Bioscience 52 (10): 883-890.

McKinney M L (2006). Urbanization as a major cause of biotic homogenization. Biological Conservation 127: 247-260.

McKinney M L (2008). Effects of urbanization on species richness: A review of plants and animals. Urban Ecosystems 11: 161-176.

McMillan B R, Kaufman D W (1995). Travel path characteristics for free-living whitefooted mice (Peromyscus leucopus). Canadian Journal of Zoology 73(8): 14741478.

Meiners S J (2007). Apparent competition: an impact of exotic shrub invasion on tree regeneration. Biological Invasions 9: 849-855.

Miller K E, Gorchov D L (2004). The invasive shrub, Lonicera maackii, reduces growth and fecundity of perennial forest herbs. Oecologia 139: 359-375.

Munshi-South J (2012). Urban landscape genetics: canopy cover predicts gene flow between white-footed mouse (Peromyscus leucopus) populaiton in New York City. Molecular Ecology 21(6): 1360-1278.

Munshi-South J, Kharchenko K (2010). Rapid, pervasive genetic differentiation of urban white-footed mouse (Peromyscus leucopus) populations in New York City. Molecular Ecology 19: 4242-4254.

Nielsen A B, van den Bosch M, Maruthaveeran S, van den Bosch C K (2014). Species richness in urban parks and its drivers: A review of empirical evidence. Urban Ecosystems 17: 305-327.

Niggemann M, Jetzkowitz J, Brunzel S, Wichmann M C, Bialozyt R (2009). Distribution patterns of plants explained by human movement behavior. Ecological Modeling 220(9-10): 1339-1346.

Novčić B, Damnjanović V (2012). Serbia brand identity: perspectives of residents and diaspora. Euromed Journal of Business 7(3): 256-267. 
Oke T R (1982). The Energetic Basis of the Urban Heat-Island. Quaterly Journal of the Royal Meteorological Society 108: 1-24.

Orrock J L, Baskett M L, Holt R D (2010). Spatial interplay of plant competition and consumer foraging mediate plant coexistence and drive the invasion ratchet. Proceedings of the Royal Society B: Biological Sciences 277(1698): 3307-3315.

Orrock J L, Danielson B J (2009). Temperature and cloud cover, but not predator urine, affect winter foraging of mice. Ethology 115: 641-648.

Orrock J L, Danielson B J, Brinkerhoff R J (2004). Rodent foraging is affected by indirect, but not by direct, cues of predation risk. Behavioral Ecology 15: 433437.

Pearson D E, Ortega Y K (2001). Evidence of an indirect dispersal pathway for spotted knapweed, Centaurea maculosa, seeds, via deer mice, Peromyscus maniculatus, and great horned owls, Bubo virginianus. The Canadian Field-Naturalist 115(2): 354-354.

Pennington D N, Hansel J R, Gorchov D L (2010). Urbanization and riparian forest woody communities: diversity, composition, and structure within a metropolitan landscape. Biological Conservation 143: 182-194.

Pickett S T A, Cadenasso M L, Grove J M, Boone C G, Groffman P M, Irwin E, Kaushal S S, Marshall V, McGrath B P, Nilon C H, Pouyat R V, Szlavecz K, Troy A,Warren P (2011). Urban ecological systems: scientific foundations and a decade of progress. Journal of Environmental Management 92: 331-362.

Planz J V, Kirkland G L (1992). Use of woody ground litter as a substrate for travel by the white-footed mouse, Peromyscus-leucopus. The Canadian Field-Naturalist 106: 118-121.

Polak T, Korine C, Yair S, Holderied M W (2011). Differential effects of artificial lighting on flight and foraging behaviour of two sympatric bat species in a desert. Journal of Zoology 285: 21-27.

Predick K I, Turner M G (2008). Landscape configuration and flood frequency influence invasive shrubs in floodplain forests of the Wisconsin River (USA). Journal of Ecology 96(1): 91-102.

Preisser E L, Bolnick D I, Benard M F (2005). Scared to death? The effects of intimidation and consumption in predator-prey interactions. Ecology 86: 501509. 
Prugh L R, Golden C D (2014). Does moonlight increase predation risk? Meta-analysis reveals divergent responses of nocturnal mammals to lunar cycles. Journal of Animal Ecology 83: 504-514.

R Core Team (2015). R: A language and environment for statistical computing. R Foundation for Statistical Computing, Vienna, Austria. URL http://www.Rproject.org.

Rose C L, Turk P J, Selego S M, Anderson J T (2014). White-footed mice (Peromyscus leucopus) select fruits of native species over invasive honeysuckle fruits. Journal of Mammalogy 95: 108-116.

Schmidt K A (2000). Interactions between food chemistry and predation risk in fox squirrels. Ecology 81: 2077-2085.

Schmidt K A, Brown J S, Morgan R A (1998). Plant defense as complementary resources: a test with squirrels. Oikos 81: 130-142.

Schmidt K A, Goheen J R, Naumann R, Ostfeld R S, Schauber E M, Berkowitz A (2001). Experimental removal of strong and weak predators: mice and chipmunks preying on songbird nests. Ecology 82(10): 2927-2936.

Schmidt K A, Ostfeld R S (2003). Mice in space: space use predicts the interaction between mice and songbirds. Ecology 84(12): 3276-3283.

Schmidt K A, Whelan C J (1999). Effects of exotic Lonicera and Rhamnus on songbird nest predation. Conservation Biology 13(6): 1502-1506.

Schoener T W (1971). Theory of feeding strategies. Annual Review of Ecology and Systematics 2: 369-404.

Shaner PJ, Bowers M, Macko S (2007). Giving-up density and dietary shifts in the whitefooted mouse, Peromyscus leucopus. Ecology 88(1): 87-95.

Shields J M, Jenkins M A, Zollner P A, Saunders M R (2014). Effects of Amur honeysuckle invasion and removal on white-footed mice. Journal of Wildlife Management 78: 867-880.

Shochat E, Lerman S B, Anderies J M, Warren P S, Faeth S H, Nilon C H (2010). Invasion, competition, and biodiversity loss in urb ecosystems. Bioscience 60: 199-208.

Sikes R S, Gannon W L, the Animal Care and Use Committee of the American Society of Mammalogists (2011). Guidelines of the American Society of Mammalogists for the use of wild mammals in research. Journal of Mammalogy 92: 235-253. 
Smith H T, Engeman R M (2002). An extraordinary raccoon, Procyon lotor, density at an urban park. The Canadian Field-Naturalist 116: 636-639.

Stone E L, Jones G, Harris S (2009). Street lighting disturbs commuting bats. Current Biology 19: 1123-1127.

Stracey C M, Wynn B, Robinson S K (2014). Light pollution allows the northern mockingbird (mimus polyglottos) to feed nestlings after dark. The Wilson Journal of Ornithology 126: 366-369.

van der Merwe M, Burke A M, Brown J S (2007). Foraging ecology of North American tree squirrels on cacheable and less cacheable foods: a comparison of two urban habitats. Evolutionary Ecology Research 9: 705-716.

Vilà M, Espinar J L, Hejda M, Hulme P E, Jaroŝsik V, Maron J L, Pergl J, Schaffner U, Sun Y, Pyšek P (2011). Ecological impacts of invasive alien plants: a metaanalysis of their effects on species, communities and ecosystems. Ecology Letters 14(7): 702-708.

Wall S B V (2003). How rodents smell buried seeds: A model based on the behavior of pesticides in soil. Journal of Mammalogy 84: 1089-1099.

Walsh C J, Roy A H, Feminella J W, Cottingham P D, Groffman P M, Morgan R P (2005). The urban stream syndrome: current knowledge and the search for a cure. Journal of the North American Benthological Society 24(3): 706-723.

The Weather Channel. Weather History for KLou, 40207. http://www.wunderground. com/history/airport/KLOU/2014/9/20/DailyHistory.html?req_city=Louisville\&re q_state $=$ KY\&req_statename $=$ Kentucky\&reqdb.zip $=40207 \&$ reqdb.magic $=1 \&$ reqd b.wmo=99999. Last Accessed January 28, 2015.

Whittaker J O (1966). Food of Mus musculus, Peromyscus maniculatus bairdii and Peromyscus leucopus in Vigo County, Indiana. Journal of Mammalogy 47: 473486.

Wilcove D S, Rothstein D, Dubow J, Phillips A, Losos E (1998). Quantifying threats to imperiled species in the United States. Bioscience 48: 607-615.

Williams C E (1999). Fruits of alien shrubs and deer mice: a test of the persistent fruit defense hypothesis. Journal of the Pennsylvania Academy of Science 73: 33-37.

Williams C E, Ralley J J, Taylor D H 1992. Consumption of seeds of the invasive Amur honeysuckle, Lonicera maackii (Rupr.) Maxim., by small mammals. Natural Areas Journal 12(2): 86- 89. 
Wilson J B, King W M G (1995). Human-mediated vegetation switches as processes in landscape ecology. Landscape Ecology 10(4): 191-196.

Wolf M, Batzli G (2004). Forest edge-high or low quality habitat for white-footed mice (Peromyscus leucopus)? Ecology 85: 756-769.

Yunger J A (2002). Response of two low-density populations of Peromyscus leucopus to increased food availability. Journal of Mammalogy 83: 267-279.

Zipperer W, Guntenspergen G (2009). Vegetation composition and structure of forest patches along urban-rural gradients. Pp 274-287 in Ecology of Cities and Towns: A Comparative Approach (McDonell M J, Breuste J, Hahs A K eds.) Cambridge University Press, Cambridge, Massachusets.

Zollner P A, Crane K J (2003). Influence of canopy closure and shrub coverage on travel along coarse woody debris by eastern chipmunks (Tamias striatus). American Midland Naturalist 150: 151-157.

Zollner P A, Lima S L (1999). Illumination and the perception of remote habitat patches by white-footed mice. Animal Behavior 58: 489-500. 


\section{Appendix 1 - Maps of Twin Parks}

Map 1 a) Twin Parks schematic: Upper textured band represents the primary flood channel. The lower set of textured bands represents the secondary flood channel and accompanying flood plain. Gridded areas represent the location of the two plots. Lines represent paths used by the general populace. The large shaded area represents the area covered by honeysuckle; not a consistent density. b) one subplot layout showing nine microplots, as well as trap locations. Circles represent Sherman traps. Tight gridded rectangles represent squirrel-sized Tomahawk traps; this pattern rotates 180 degrees for each of the 4 subplots in a clockwise direction. Loose gridded square represents raccoonsized tomahawk trap 
a)

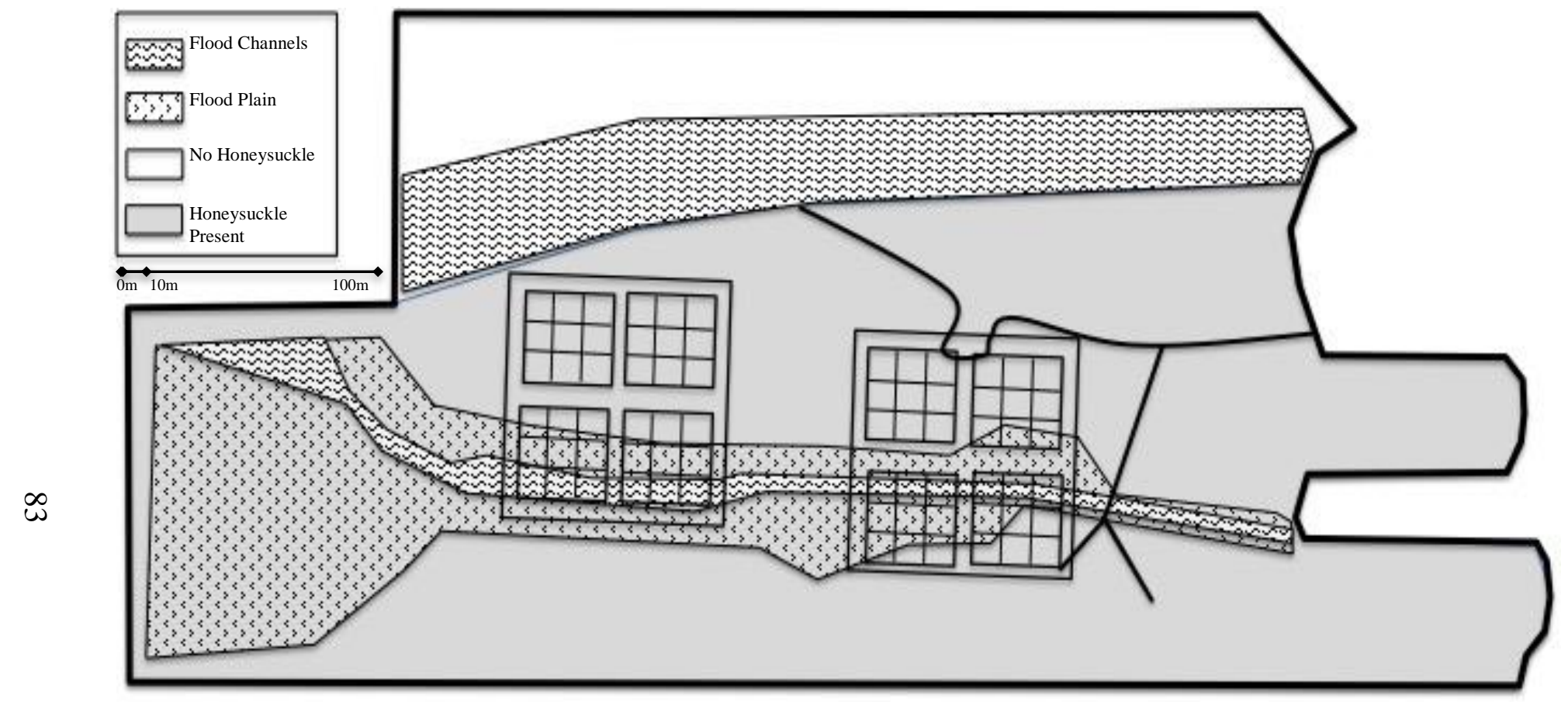


b)

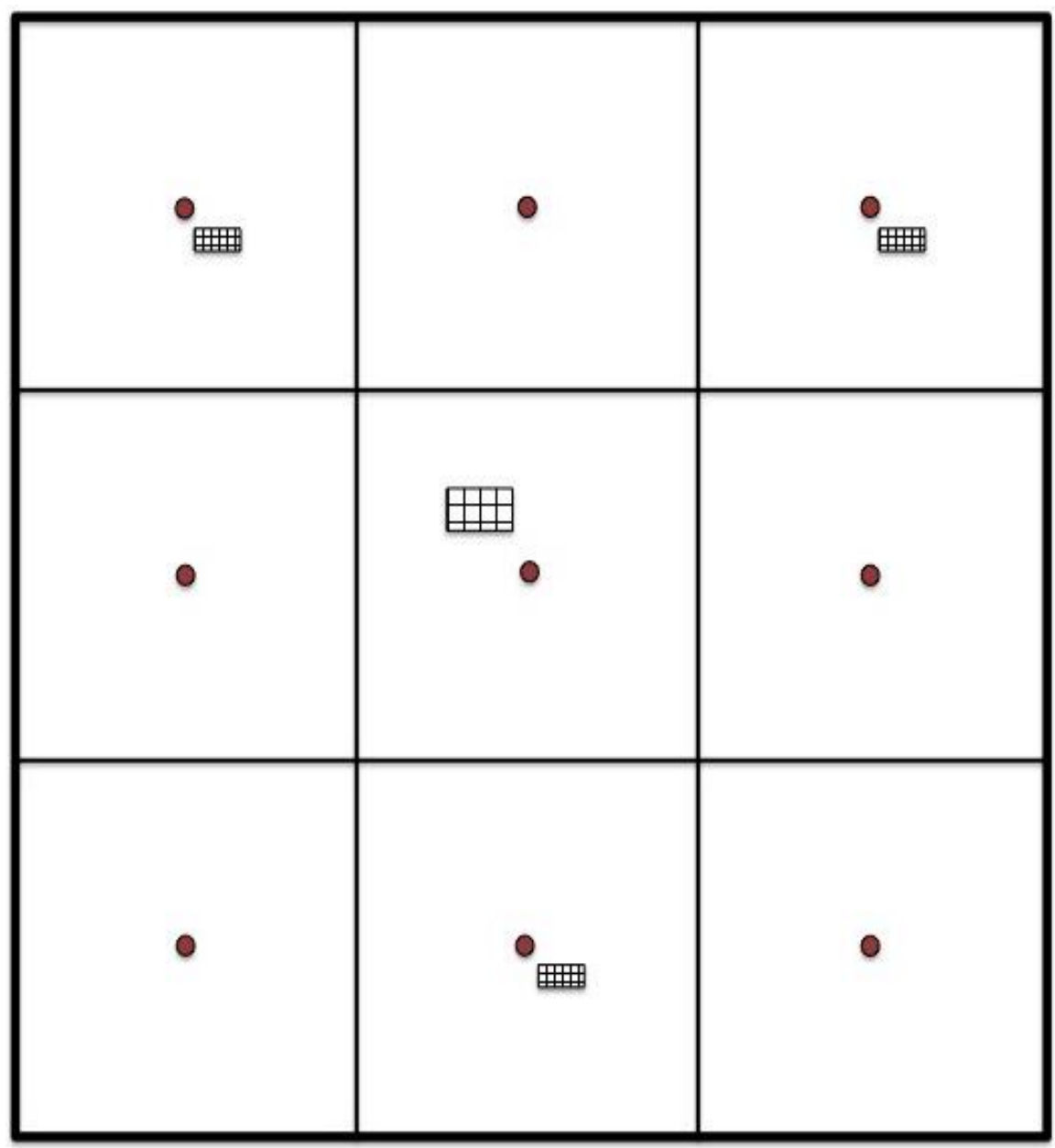


Map 2 - a) Twin Parks schematic: Upper textured band represents the primary flood channel. The lower set of textured bands represents the secondary flood channel and accompanying flood plain. X-es represent the location of 26 shrubs used in the study. Lines represent paths used by the general populace. The large shaded area represents the area covered by honeysuckle; not a consistent density.

b) Gridded layout for each of the 26 shrubs. All traps were located on the grid, and the vegetative survey used this grid for the random sample. 
a)

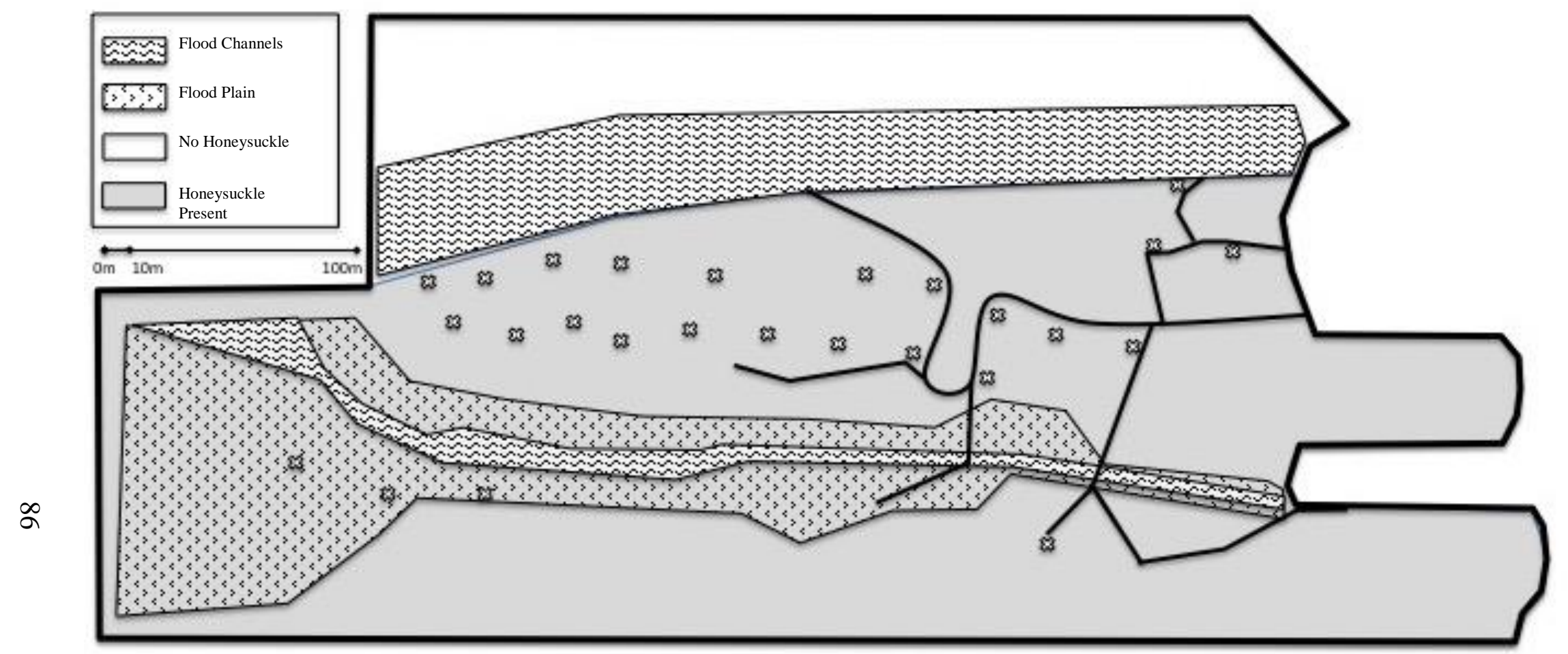


b)

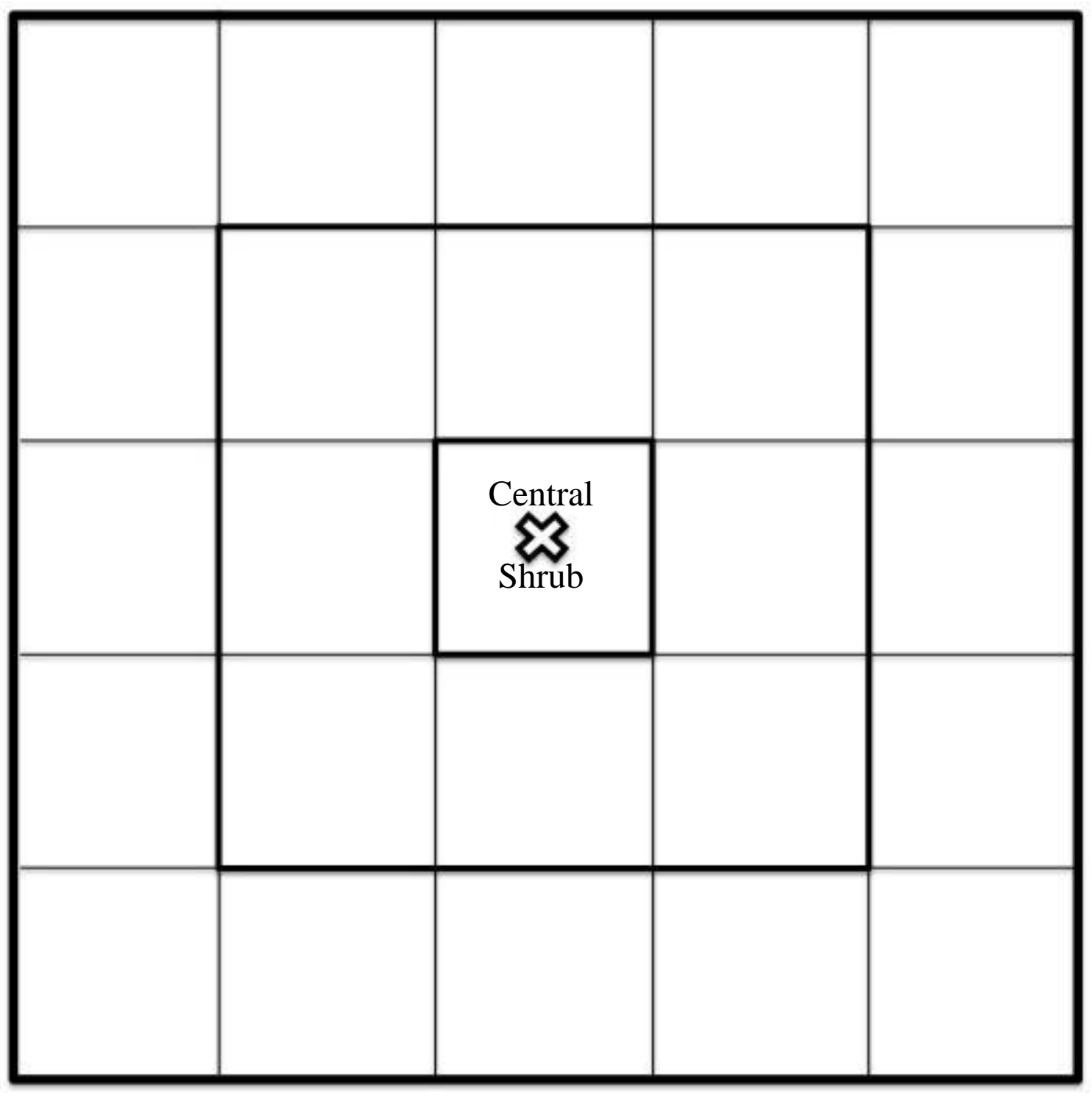




\section{Appendix 2 - Plant Species Identified on Twin Parks}

'FG' represents the functional group for each species. All grass species and all sedge species were grouped in a 'grasses' and a 'sedges' value. Number of squares is out of 1,440 individual $1 \mathrm{~m}^{2}$ sampling squares used in the vegetative survey. Number of micros is out of 72 total microplots surveyed.

\begin{tabular}{|c|c|c|c|c|c|}
\hline & & & & \# & \# \\
\hline COMMON NAME & GENUS & SPECIES & FG & squal & quadrats \\
\hline Christmas Fern & Polystichum & acrostichoides & $\mathrm{F}$ & 4 & 3 \\
\hline Grasses & & & $\mathrm{G}$ & 223 & 44 \\
\hline Bottlebrush Grass & Elymus & hystrix & $\mathrm{G}$ & 29 & 12 \\
\hline Tall Fescue & Festuca & arundinacea & $\mathrm{G}$ & 1 & 1 \\
\hline Japanese Stilt Grass & Microstegium & vimineum & $\mathrm{G}$ & 1 & 1 \\
\hline Woodland Bluegrass & Poa & sylvestris & $\mathrm{G}$ & 1 & 1 \\
\hline unknown grass 1 & & & $\mathrm{G}$ & 6 & 3 \\
\hline unknown grass 2 & & & $\mathrm{G}$ & 2 & 2 \\
\hline Forbs & & & & & \\
\hline unknown plant 6 & Acanthaceae & & $\mathrm{F}$ & 9 & 2 \\
\hline White Snakeroot & Ageratina & altissima & $\mathrm{F}$ & 22 & 9 \\
\hline Garlic Mustard & Alliaria & petiolata & $\mathrm{F}$ & 140 & 35 \\
\hline Wild Onion & Allium & crispum & $\mathrm{F}$ & 5 & 4 \\
\hline Goatsbeard & Aruncus & dioicus & $\mathrm{F}$ & 1 & 1 \\
\hline Wild Ginger & Asarum & canadense & $\mathrm{F}$ & 3 & 3 \\
\hline unknown plant 8 & Asteraceae & & $\mathrm{F}$ & 136 & 40 \\
\hline Unknown Plant 4 & Asteraceae & & $\mathrm{F}$ & 87 & 24 \\
\hline unknown plant 7 & Balsaminaceae & Impatiens & $\mathrm{F}$ & 1 & 1 \\
\hline Devil's Beggartick & Bidens & frondosa & $\mathrm{F}$ & 176 & 40 \\
\hline False Nettle & Boehmeria & cylindrica & $\mathrm{F}$ & 205 & 41 \\
\hline Lambsquarters & Chenopodium & album & $\mathrm{F}$ & 1 & 1 \\
\hline Philadelphia Fleabane & Erigeron & philadelphicus & $\mathrm{F}$ & 1 & 1 \\
\hline Cleavers & Galium & aparine & $\mathrm{F}$ & 2 & 2 \\
\hline White Avens & Geum & canadense & $\mathrm{F}$ & 300 & 60 \\
\hline Spring Avens & Geum & vernum & $\mathrm{F}$ & 317 & 63 \\
\hline Orange Jewelweed & Impatiens & capensis & $\mathrm{F}$ & 365 & 11 \\
\hline Wild Lettuce & Lactuca & virosa & $\mathrm{F}$ & 7 & 5 \\
\hline Purple Deadnettle & Lamium & purpureum & $\mathrm{F}$ & 1 & 1 \\
\hline Wood Nettle & Laportia & canadensis & $\mathrm{F}$ & 27 & 12 \\
\hline American Bugleweed & Lycopus & americanus & $\mathrm{F}$ & 3 & 2 \\
\hline
\end{tabular}




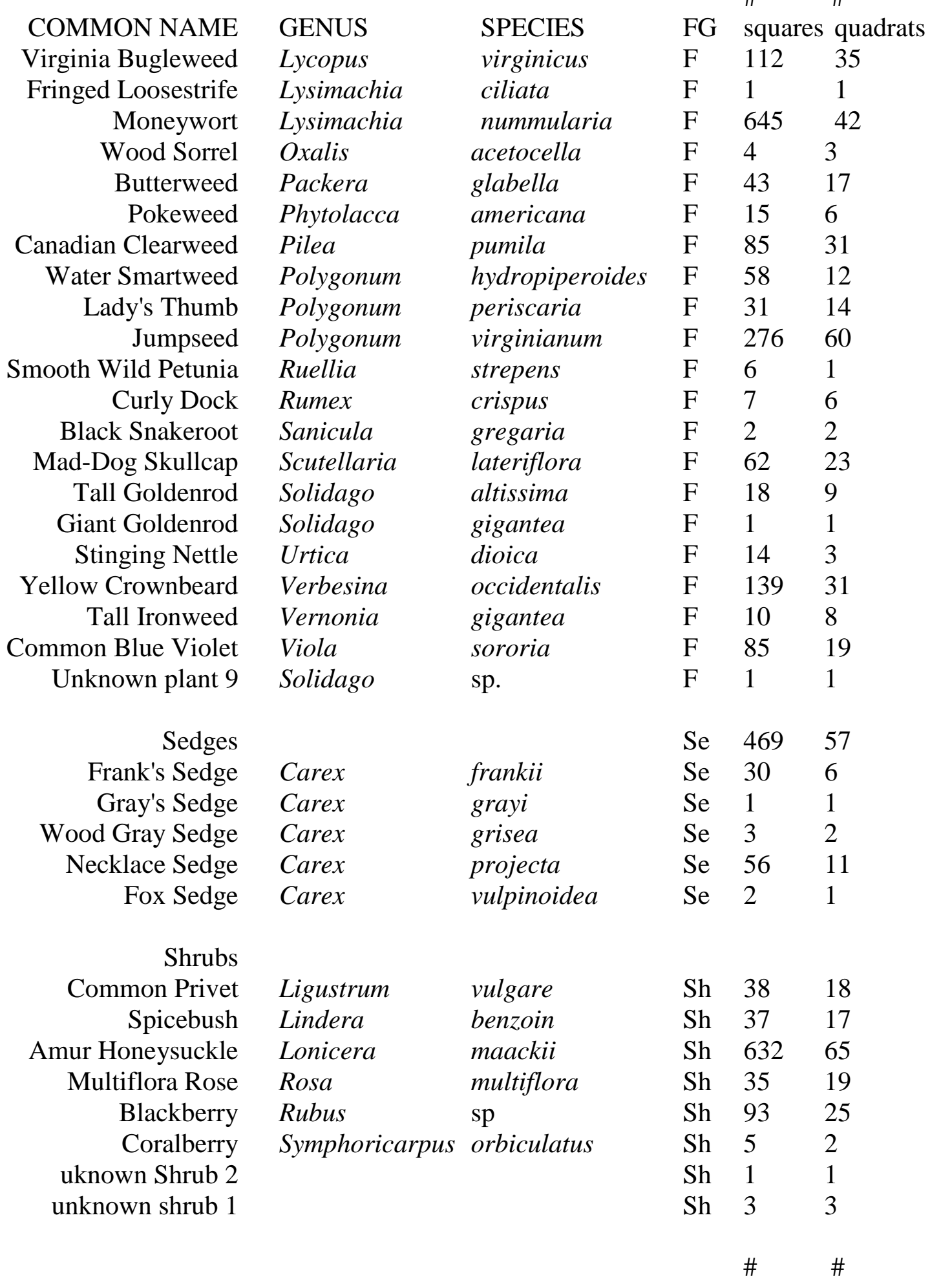




\begin{tabular}{|c|c|c|c|c|c|}
\hline COMMON NAME & GENUS & SPECIES & $\mathrm{FG}$ & \multicolumn{2}{|c|}{ squares quadrats } \\
\hline Manlio & $\Delta a r$ & snn & TS & 178 & 50 \\
\hline Mrapre sapming & Acer & spp & IS & $4 / 8$ & 58 \\
\hline Ailanthus & Ailanthus & altissima & $\mathrm{TS}$ & 2 & 1 \\
\hline Catalpa seedling & Catalpa & speciosa & $\mathrm{TS}$ & 1 & 1 \\
\hline Hackberry seedling & Celtis & spp. & $\mathrm{TS}$ & 40 & 9 \\
\hline Hawthorn seedling & Crataegus & sp. & $\mathrm{TS}$ & 6 & 5 \\
\hline Ash seedling & Fraxinus & spp. & $\mathrm{TS}$ & 489 & 62 \\
\hline Locust seedling & Gleditsia & Robinia & $\mathrm{TS}$ & 4 & 4 \\
\hline Sweetgum seedling & Liquidambar & styraciflua & $\mathrm{TS}$ & 33 & 13 \\
\hline Tulip Poplar seedling & Liriodendron & tulipifera & $\mathrm{TS}$ & 47 & 13 \\
\hline Mulberry Saplings & Morus & spp. & $\mathrm{TS}$ & 37 & 12 \\
\hline Unknown seedling 1 & Pyrus & $\mathrm{sp}$ & $\mathrm{TS}$ & 10 & 8 \\
\hline Sycamore & Platanus & sp. & $\mathrm{TS}$ & 3 & 3 \\
\hline Cherry seedling & Prunus & serotina & $\mathrm{TS}$ & 2 & 2 \\
\hline Oak sapling & Quercus & spp. & $\mathrm{TS}$ & 9 & 8 \\
\hline Buckthorn seedling & Rhamnus & sp. & $\mathrm{TS}$ & 11 & 7 \\
\hline Elm sapling & Ulmus & spp. & $\mathrm{TS}$ & 42 & 34 \\
\hline Vine & & & & & \\
\hline Amur Peppervine & Ampelopsis & brevipedunculata & $\mathrm{V}$ & 21 & 15 \\
\hline Hog Peanut & Amphicarpaea & bracteata & $\mathrm{V}$ & 54 & 24 \\
\hline Hedge Bindweed & Calystegia & sepium & $\mathrm{V}$ & 4 & 3 \\
\hline Trumpet Vine & Campsis & radicans & $\mathrm{V}$ & 60 & 22 \\
\hline False Strawberry & Duchesnea & indica & $\mathrm{V}$ & 170 & 46 \\
\hline Wild Cucumber Vine & Echynocystis & lobata & $\mathrm{V}$ & 2 & 2 \\
\hline Winter Creeper & Euonymus & fortunei & $\mathrm{V}$ & 413 & 63 \\
\hline Wild Sweet Potato Vine & Ipomoea & pandurata & $\mathrm{V}$ & 11 & 8 \\
\hline Honeysuckle Vine & Lonicera & japonica & $\mathrm{V}$ & 208 & 43 \\
\hline Moonseed Vine & Menispermun & canadense & $\mathrm{V}$ & 4 & 4 \\
\hline Virginia Creeper & Parthenoscissus & quinquefolia & $\mathrm{V}$ & 344 & 52 \\
\hline Common Greenbriar & Smilax & rotundifolia & $\mathrm{V}$ & 17 & 15 \\
\hline Poison Ivy & Toxicodendron & radicans & $\mathrm{V}$ & 424 & 60 \\
\hline Frost grape & Vitis & vulpina & $\mathrm{V}$ & 116 & 45 \\
\hline
\end{tabular}




\section{TREE SPECIES}

$\begin{array}{rll}\text { COMMON NAME } & \text { GENUS } & \text { SPECIES } \\ \text { Boxelder } & \text { Acer } & \text { negundo } \\ \text { Norway Maple } & \text { Acer } & \text { norvegicus } \\ \text { Red Maple } & \text { Acer } & \text { rubrum } \\ \text { Silver Maple } & \text { Acer } & \text { saccharinum } \\ \text { Ailanthus } & \text { Ailanthus } & \text { altissima } \\ \text { Common Pawpaw } & \text { Asimina } & \text { triloba } \\ \text { Pignut Hickory } & \text { Carya } & \text { glabra } \\ \text { Northern Catalpa } & \text { Catalpa } & \text { speciosa } \\ \text { Southern Hackberry } & \text { Celtis } & \text { laevigata } \\ \text { Northern Hackberry } & \text { Celtis } & \text { occidentalis } \\ \text { Eastern Redbud } & \text { Cercis } & \text { candensis } \\ \text { Flowering Dogwood } & \text { Cornus } & \text { florida } \\ \text { American Beech } & \text { Fagus } & \text { grandifolia } \\ \text { White Ash } & \text { Fraxinus } & \text { americana } \\ \text { Green Ash } & \text { Fraxinus } & \text { pennsylvanica } \\ \text { Honey Locust } & \text { Gleditsia } & \text { triacanthos } \\ \text { Black Walnut } & \text { Juglans } & \text { nigra } \\ \text { Sweetgum } & \text { Liquidambar } & \text { styraciflua } \\ \text { Osage-Orange } & \text { Maclura } & \text { pomifera } \\ \text { White Mulberry } & \text { Morus } & \text { alba } \\ \text { Red Mulberry } & \text { Morus } & \text { rubra } \\ \text { Sycamore } & \text { Platanus } & \text { occidentalis } \\ \text { Elack Cherry } & \text { Prunus } & \text { deltoides } \\ \text { serotina } \\ \text { American Basswood } & \text { Tilia } & \text { americana } \\ \text { American Elm } & \text { Ulmus } & \text { americana } \\ \text { Chinese Elm } & \text { Ulmus } & \text { parvifolia } \\ & & \end{array}$




\section{CURRICULUM VITAE}

NAME: William E Persons

ADDRESS: Department of Biology

139 Life Sciences

University of Louisville

Louisville, KY 40292

\section{Teaching Experience}

Professional

Bellarmine University

Biol 130 Intro Biol lab

Biol 140 Animal Diversity lab

Spalding University

ENVS 101 Living Green

ENVS 101 Living Green - AAP
Fall 2015-Spring 2016

majors

majors

Fall 2015- Spring 2016

non majors

non-major, returning students
Graduate

Spring 2015

2010 - present

Summer 2013, 14

2013

$2011-2013$

Summer 2008
Biology 102 - Intro Biology - Guest lecture

Graduate Teaching Assistant, Biology 104

Graduate Teaching Assistant, Biology 244

Graduate Research Assistant, Horner Bird Sanctuary

Endowment

Volunteer Educator, Engaging Children Outdoors (ECHO)

Summer intern, Louisville Nature Center

Academic Career

University of Louisville

University of Louisville

Doctoral Candidate

2012 - December 2015

Organismal Biology

B.A., 2010

Research

$2011-2015$

$2011-2013$

$2010-2011$

2010

$2009-2010$
Dissertation Research in Louisville, Ky

Research Coordinator, Urban Wildlife Research Lab

Graduate Researcher, Urban Wildlife Research Lab

Field Technician, Myotis bat research, University of Missouri

Undergraduate Researcher, Urban Wildlife Research Lab 


\section{Service}

$2012-2013$

$2008-2012$

$2003-2005$

Team Leader, Raptor Rehabilitation of Kentucky

$1998-2005$

Volunteer, Raptor Rehabilitation of Kentucky

Junior Assistant Scoutmaster, Troop 24

Boy Scouts of America, Troop 24

\section{Research Interests}

Biological invasion theory and behavioral adaptations in small mammals; behavioral ecology, mammal behavior, invasion ecology; Human impact on green areas and resultant response trajectories of faunal and floral community

\section{Publications}

Persons, W E (2015). Working in the forest - a story of campus trees: Inventorying trees at the University of Louisville. Sustain 33:41-45.

Parker TS, Persons WE, Bradley JG, Gregg M, Gonzales SK, Helton JS (2013) A Detachable Mobile and Adjustable Telemetry System. Ecology and Evolution 3 (7) 1848-1855.

\section{Popular Press}

Interviewed article; Odyssey Science Magazine - February 2013. "Bill Persons Squirrel Tracker"

\section{Presentations}

\section{Talks}

2015 UofL Biology Awards Day - Factors affecting small mammal community distribution and foraging strategies in an urban park.

2015 Guest Lecture Introductory Biology (nonmajors) - Biotic Impacts of Climate

Invited Talks Change, and Future Trends

2014 Ball State University - Small Mammals alter Population Structure and Microhabitat Use Dynamics in Urban Areas in Response to an Invasive Species, Amur honeysuckle (Lonicera maackii)

Conference Talks

2013 Kentucky Academy of Sciences Conference - Factors Affecting Small Mammal Movement in an Amur honeysuckle (Lonicera maackii) dominated urban park.

2013 School of Grounds Management PGMS Conference - Panel Discussion: Promoting Sustainable Landscape: A Case Study from the University of Louisville.

Posters

2014 Small Mammal Movement and Microhabitat Selection Preferences in an Amur honeysuckle (Lonicera maackii) Dominated Urban Park. Undergraduate Research

$201398^{\text {th }}$ Annual ESA Conference - Small Mammal movement patterns in an Amur honeysuckle (Amur maackii) dominated urban park. PS 86-170 


\section{Grants and Awards}

Grants

2013 Graduate Student Council Research Grant - \$300.00 - Field equipment needed, Wildlife Techniques Manual, $7^{\text {th }}$ ed.

2013 Biology Department Horner Conservancy Grant - \$1,082.00 -Small Mammals Alter Community structure and microhabitat use dynamics in urban areas in response to an invasive species.

2013 Graduate Student Union Travel and Research Grant - \$100.00 - Supplies for preparing mammal skins as Museum specimens

2012 Graduate Student Union Travel and Research Grant - \$100.00 - Memphis trip to visit Dr. Michael Kennedy

Awards

2013 Award - School for Interdisciplinary Studies Honor award for active participation and service as a member of Graduate Student Council

2005 Army Recruiter Ribbon for Excellence in Leadership

$2003 \quad$ Eagle Scout Award

\section{Workshops}

2011 ECHO Professional Development Seminar, Jefferson Memorial Forest

2010 National Science Foundation Day, Kentucky State University

\section{Society Memberships}

2014-present

American Society of Mammalogists

2011-present

Ecological Society of America

2011-present The Wildlife Society 